Check for updates

Cite this: RSC Adv., 2018, 8, 3328

Received 20th October 2017 Accepted 9th January 2018

DOI: 10.1039/c7ra11603a

rsc.li/rsc-advances

\section{Theoretical investigation on the ground state properties of the hexaamminecobalt(III) and nitro- nitrito linkage isomerism in pentaamminecobalt(III) in vacuo†}

\begin{abstract}
Jules Tshishimbi Muya, (D) *a Hoeil Chung (D)*a and Sang Uck Lee (D)*bc
Nitro-nitrito isomerization in $\mathrm{Co}\left(\mathrm{NH}_{3}\right)_{5} \mathrm{NO}_{2}{ }^{2+}$ linkage isomers was investigated with a focus on the geometries, relative stabilities and chemical bonding using $\omega \mathrm{B} 97 \mathrm{XD} / 6-31+\mathrm{G}(\mathrm{d}, \mathrm{p})$ to elucidate the photosalient effect in $\left[\mathrm{Co}\left(\mathrm{NH}_{3}\right)_{5} \mathrm{NO}_{2}\right] \mathrm{NO}_{3} \mathrm{Cl}$. Different techniques like atoms in molecules (AIM), electron localization function (ELF) and natural bonding orbital (NBO) were used to gain insight into the chemical bonds of the isomers and to identify the key factors influencing their relative stabilities. The study of the ground-state potential energy surface of $\left[\mathrm{Co}\left(\mathrm{NH}_{3}\right)_{5} \mathrm{NO}_{2}\right]^{2+}$ reveals that the nitro/exo-nitrito isomerization reaction can proceed via the following two paths: (1) nitro $\rightarrow$ TS1 $\left(38.16 \mathrm{kcal} \mathrm{mol}^{-1}\right.$ ) $\rightarrow$ endo-nitrito $\rightarrow$ TS2 $\left(9.68 \mathrm{kcal} \mathrm{mol}^{-1}\right) \rightarrow$ exo-nitrito and (2) nitro $\rightarrow$ TS3 (41.76 kcal mol ${ }^{-1}$ ) $\rightarrow$ exo-nitrito. Pathway (1) through endo-nitrito is the most likely isomerization mechanism because of a lower energy barrier than pathway (2). The intramolecular-resonance-assisted hydrogen bonds $(\mathrm{N}-\mathrm{H} \cdots \mathrm{O}$ and $\mathrm{N}-\mathrm{H} \cdots \mathrm{N})$, the orientation of $\mathrm{NO}_{2}$, and the difference between $\mathrm{CO}-\mathrm{N}$ and $\mathrm{CO}-\mathrm{O}$ bond energies are identified as the key factors determining the relative stabilities of the linkage isomers. $\mathrm{Co}\left(\mathrm{NH}_{3}\right)_{6}{ }^{3+}$ is less stable compared to $\mathrm{Co}\left(\mathrm{NH}_{3}\right)_{5} \mathrm{NO}_{2}{ }^{2+}$ and undergoes a slight geometrical distortion from $D_{3 d}$ to either $D_{3}$ or $S_{6}$ characterized by a stabilization energy of $\sim 750 \mathrm{~cm}^{-1}$ at $\operatorname{CCSD}(T) / 6-31+G(d, p)$.
\end{abstract}

\section{Introduction}

Co complexes play various important roles in the chemistry of life processes and have been known for ages to impart blue color to ceramics. ${ }^{\mathbf{1 , 2}}$ Considerable research effort has been made to understand the properties of Co complexes, particularly those derived from cobaltammines. Sakiyama et $a .^{3}$ analyzed the electronic spectra of the hexaamminecobalt(III) complex cation in aqueous solution to obtain the spectral components attributed to the slight distortion from a regular octahedron around the central cobalt(III) ion and reported that the LC-BLYP/ 6-31G(d) optimized geometry of the complex in aqueous solution is a trigonally compressed octahedron under $D_{3 \mathrm{~d}}$. The influence of this reduction in the symmetry of $\left[\mathrm{Co}\left(\mathrm{NH}_{3}\right)_{6}\right]^{3+}$ on its vibrational spectrum was also examined in the solid state. ${ }^{4}$ This trigonal deformation was reported to be sensitive to the environment of the complex. ${ }^{3}$ A crystallographic study of the

${ }^{a}$ Hanyang University, Department of Chemistry, Seoul, South Korea. E-mail: hoeil@ hanyang.ac.kr; julescmuya.tmuya@gmail.com

${ }^{b}$ Hanyang University, Department of Chemical \& Molecular Engineering, Sangnok-gu, Ansan 426-791, Korea. E-mail: sulee@hanyang.ac.k

${ }^{c}$ Hanyang University, Department of Bionanotechnology, Sangnok-gu, Ansan 426-791, Korea

$\dagger$ Electronic supplementary information (ESI) available. See DOI: 10.1039/c7ra11603a binding of oxo-anions with cationic cobaltammine carried out by Sharma et al. ${ }^{5}$ revealed the presence of discrete $\left[\mathrm{Co}\left(\mathrm{NH}_{3}\right)_{6}\right]^{3+}$ ions and mixed anions (e.g. $\mathrm{Cl}^{-}$and $\mathrm{ClO}_{3}{ }^{-}, \mathrm{Br}^{-}$and $\mathrm{ClO}_{3}{ }^{-}, \mathrm{Cl}^{-}$ and $\mathrm{ClO}_{3}{ }^{-}$) which are stabilized by hydrogen bonding interactions and attractive electrostatic forces. The hexaamminecobalt(III) complex cation is a potential anion receptor $^{5,6}$ widely used in structural biology to characterize biomolecules like DNA, RNA, and proteins ${ }^{7}$ and it is considered as a representative cationic Werner complex. It is worth mentioning that the works of Alfred Werner on cobaltammines led to a Nobel Prize in $1913,{ }^{8}$ which formed the basis of modern transition-metal coordination complex chemistry, especially the linkage of atoms in transition metal compounds.

Transition-metal linkage isomers have the same chemical composition, differing only in the nature of the metal-ligand connectivity. ${ }^{9}$ For example, when one ammonia in hexaamminecobalt(III) is substituted by a nitrite anion, nitro, endonitrito, and exo-nitrito isomers are formed (Fig. 1). Nitrite anion is an ambident ligand with electronic density delocalized on both $\mathrm{N}-\mathrm{O}$ bonds, and both $\mathrm{N}$ and $\mathrm{O}$ atoms acting as alternative reactive sites. It can bind to the metal through $\mathrm{N}$ as well as through $\mathrm{O}$, leading to linkage isomerism. The ambident reactivity of the nitrite ion was studied in detail by Tishkov et al. ${ }^{\mathbf{1 0}}$ For instance, the cationic cobalt complex of formula $\left[\mathrm{Co}\left(\mathrm{NH}_{3}\right)_{5} \mathrm{NO}_{2}\right] \mathrm{Cl}_{2}$ exists as either the yellow-colored nitro 


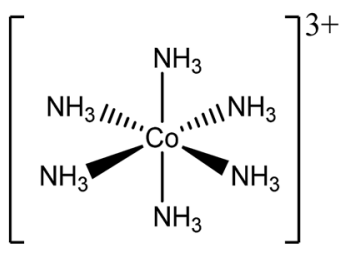

(a)

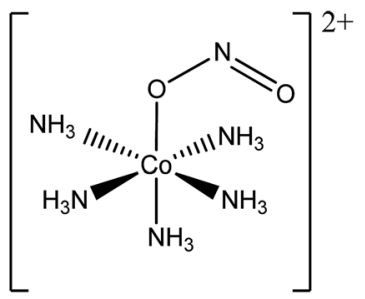

(d) endo-Co-ONO

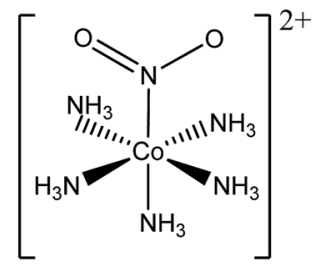

(b) $\mathrm{Co}-\mathrm{NO}_{2}$

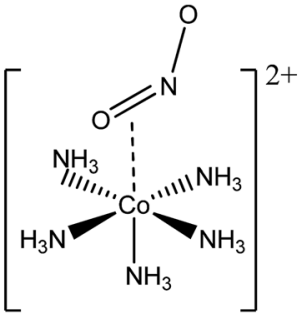

(d) $M-\pi$ interaction isomer

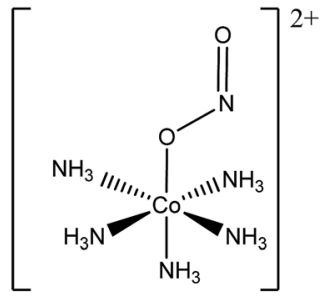

(c ) exo-Co-ONO

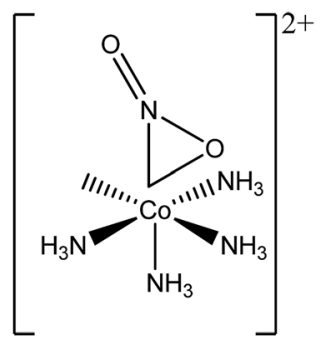

(e) $(\mathrm{N}, \mathrm{O})$-chelate isomer

Fig. 1 Initial geometries of: (a) hexaamminocobalt(III) cation, (b-c) $N$ - and $O$-linked Co-complexes isomers, (d) $M-\pi$ interaction Co-complex isomer, and $(\mathrm{e})(\mathrm{N}, \mathrm{O})$-chelate Co-complex isomer.

isomer $\left(\left[\mathrm{Co}\left(\mathrm{NH}_{3}\right)_{5} \mathrm{NO}_{2}\right] \mathrm{Cl}_{2}\right)$, where the nitro ligand is bound to Co through nitrogen, or the red-colored nitrito isomer $\left(\left[\mathrm{Co}\left(\mathrm{NH}_{3}\right)_{5} \mathrm{ONO}\right] \mathrm{Cl}_{2}\right)$, where the nitrito is bound to Co through one of the oxygen atoms ${ }^{11-16}$ Several research groups have focused their studies on metal linkage compounds due to their potential applications in medicinal therapy, photo-responsive materials, tunable optical materials, and molecular devices. ${ }^{\mathbf{1 1 - 1 3 , 1 7 - 2 6}}$

The transformation of the N-bonded nitro isomer to the less stable O-bonded nitrito isomer has already been extensively studied experimentally and the conversion was demonstrated to occur intramolecularly. ${ }^{13-16}$ The nitrito isomers of $\left[\mathrm{Co}\left(\mathrm{NH}_{3}\right)_{5}\right.$ $\mathrm{ONO}]\left(\mathrm{NO}_{3}\right)_{2}$ and $\left[\mathrm{Co}\left(\mathrm{NH}_{3}\right)_{5} \mathrm{ONO}\right]\left(\mathrm{NO}_{3}\right) \mathrm{Cl}$ convert slowly to the respective nitro isomers $\left[\mathrm{Co}\left(\mathrm{NH}_{3}\right)_{5} \mathrm{NO}_{2}\right]\left(\mathrm{NO}_{3}\right)_{2}$ and $\left[\mathrm{Co}\left(\mathrm{NH}_{3}\right)_{5}-\right.$ $\left.\mathrm{NO}_{2}\right]\left(\mathrm{NO}_{3}\right) \mathrm{Cl}$ when placed in a dark room. ${ }^{19}$ The base dependence of this linkage isomerization and the transformation of the nitrito in nitrito was also observed overnight by Jackson et $a .^{27}$ in $\left[\mathrm{Co}\left(\mathrm{NH}_{3}\right)_{5} \mathrm{ONO}\right]\left(\mathrm{ClO}_{4}\right)$ in solution using $\mathrm{H}^{1} \mathrm{NMR}$ and UV-vis techniques. The reaction of the transformation of $\left[\mathrm{Co}\left(\mathrm{NH}_{3}\right)_{5} \mathrm{ONO}\right]^{2+}$ in $\left[\mathrm{Co}\left(\mathrm{NH}_{3}\right)_{5} \mathrm{NO}_{2}\right]^{2+}$ in solution and in solid state was found to be accelerated by light. ${ }^{27-29}$ More detailed information related to the experiments describing the synthesis of $\left[\mathrm{Co}\left(\mathrm{NH}_{3}\right)_{5} \mathrm{NO}_{2}\right]^{2+}$ and $\left[\mathrm{Co}\left(\mathrm{NH}_{3}\right)_{5} \mathrm{ONO}\right]^{2+}$ and the application of spectroscopic techniques to detect the nitrite bonding mode are provided elsewhere..$^{27,29-32}$ Here we only recall that this transformation may pass through an intermediate endo$\left[\mathrm{Co}\left(\mathrm{NH}_{3}\right)_{5} \mathrm{ONO}\right]^{2+}$. According to Ciofini, ${ }^{33}$ experimental data do not provide a better understanding of the nitro/nitrito transformation mechanism, and theoretical methods can help in the elucidation of this reaction mechanism. This solid-state intramolecular reaction changes the configuration of the $\left[\mathrm{Co}\left(\mathrm{NH}_{3}\right)_{5} \mathrm{NO}_{2}\right]^{2+}$ complex cation alone at its site in the lattice, leaving the rest of the lattice unchanged ${ }^{9}$ and was reported to be autocatalytic or auto-inhibitory. ${ }^{24}$ In contrast to the dark condition, Naumov et al. ${ }^{22,23}$ reported that the $\left[\mathrm{Co}\left(\mathrm{NH}_{3}\right)_{5^{-}}\right.$ $\left.\mathrm{NO}_{2}\right]\left(\mathrm{NO}_{3}\right) \mathrm{Cl}$ crystal exhibits a forceful jump when exposed to UV light (referred to as the photo-salient effect). During this photo-isomerization process, $\left[\mathrm{Co}\left(\mathrm{NH}_{3}\right)_{5} \mathrm{ONO}\right]^{2+}$ was thought to serve as a local source of strains. ${ }^{24,25}$

The discovery of photo-induced leaping in $\left[\mathrm{Co}\left(\mathrm{NH}_{3}\right)_{5}-\right.$ ONO] $\left(\mathrm{NO}_{3}\right) \mathrm{Cl}$ crystals stimulated extensive research into its structural and photo-rearrangement properties. ${ }^{2,23,34,35}$ The design of dynamic molecular crystals with properties that can be controlled by applying an external stimulus is an important challenge in molecular materials science. Herein we investigate in detail the geometry, relative stability, and chemical bonding in the ground state of the hexaamminecobalt(III) cation and the nitro-/nitrito-pentaamminecobalt(III) linkage isomers (denoted as $\mathrm{Co}-\mathrm{NO}_{2}$ and $\left.\mathrm{Co}-\mathrm{ONO}\right)$ in vacuo using $\omega \mathrm{B} 97 \mathrm{XD} / 6-31+\mathrm{G}(\mathrm{d}, \mathrm{p})$. Knowledge of the structural and electronic properties of the nitro-/nitrito-pentaamminecobalt(III) linkage isomers is critical in the research of novel linked isomers with switchable optical properties. The main purpose of this study is the prediction of the pathway of the nitro-/nitrito-pentaamminecobalt(III) isomerization because the latter is the probable cause of the photosalient effect in $\left[\mathrm{Co}\left(\mathrm{NH}_{3}\right)_{5} \mathrm{ONO}\right]\left(\mathrm{NO}_{3}\right) \mathrm{Cl}$.

This study is organized as follows:

(1) First, the relative stability of $\mathrm{Co}\left(\mathrm{NH}_{3}\right)_{6}{ }^{3+}$ having $D_{3 \mathrm{~d}}$ symmetry in vacuo is analyzed using group theory and various quantum chemical methods. Contrary to literature reports, we found $\left[\mathrm{Co}\left(\mathrm{NH}_{3}\right)_{6}\right]^{3+}$ to be unstable in $D_{3 \mathrm{~d}}$ (possessing 6 imaginary frequencies) and it tends to distort towards either $D_{3}$ or $S_{6}$. $\left[\mathrm{Co}\left(\mathrm{NH}_{3}\right)_{6}\right]^{3+}$ is compared to its analogous complexes e.g. $\left[\mathrm{Ru}\left(\mathrm{NH}_{3}\right)_{6}\right]^{3+},\left[\mathrm{Cr}\left(\mathrm{NH}_{3}\right)_{6}\right]^{3+}$ and $\left[\mathrm{Fe}\left(\mathrm{NH}_{3}\right)_{6}\right]^{2+}$ at B3LYP/LanL2DZ. This $D_{3}$ geometry was afterwards used in an isodesmic reaction to compute the formation energies of $\left[\mathrm{Co}\left(\mathrm{NH}_{3}\right)_{5} \mathrm{NO}_{2}\right]^{2+}$ isomers. 
(2) Secondly, MP2, CCSD, B3LYP, B3LYP-D3, M062X, LCBLYP, and $\omega$ B97XD methods are compared with $\operatorname{CCSD}(\mathrm{T})$. The $\omega$ B97XD and LC-BLYP methods gave good results approaching $\operatorname{CCSD}(\mathrm{T})$. Therefore, the subsequent analysis is performed using $\omega$ B97XD.

(3) Thirdly, the thermodynamics and kinetics of the $\mathrm{Co}\left(\mathrm{NH}_{3}\right)_{5} \mathrm{NO}_{2}{ }^{2+}$ isomers are studied at the ${ }_{6 \mathrm{~B}} 97 \mathrm{XD}$ level, and two nitro/exo-nitrito isomerization reaction paths are identified: (1) nitro $\rightarrow$ TS1 $\left(38.16 \mathrm{kcal} \mathrm{mol}^{-1}\right) \rightarrow$ endo-nitrito $\rightarrow$ TS2 $\left(9.68 \mathrm{kcal} \mathrm{mol}^{-1}\right) \rightarrow$ exo-nitrito and (2) nitro $\rightarrow$ TS3 $\left(41.76 \mathrm{kcal} \mathrm{mol}^{-1}\right) \rightarrow$ exo-nitrito. The most likely reaction is the one that follows pathway (1) because it is the lowest-energy path.

(4) Lastly, the nature of chemical bonding in the nitro- and nitrito linkage isomers is examined briefly to understand how atoms are held together and to identify key factors to justify their order of stabilities. Hydrogen bonds, orientation of atoms in ONO group, and difference in natural bonding orbital (NBO) energy between $\mathrm{Co}-\mathrm{N}$ and $\mathrm{Co}-\mathrm{O}$ bonds are identified as the key factors to explain the relative stabilities of linkage isomers.

We confirmed through this analysis that the reaction path (1) through endo-nitrito is the most likely isomerization mechanism causing photo-salient effect, because it is the lowest energy reaction path.

\section{Computational details}

Fig. 1 shows the initial geometric structures used herein for geometry optimization. The $\left[\mathrm{Co}\left(\mathrm{NH}_{3}\right)_{5} \mathrm{NO}_{2}\right]^{2+}$ linkage isomers were constructed following the coordination modes proposed in literature. ${ }^{36,37}$ Fig. 1c and d display two O-bonded nitrito isomers with different spatial orientation of the atoms of the ONO group, denoted as exo-Co-ONO and endo-Co-ONO. Only singlet states were considered in the present study because octahedral Co(III) prefers the low-spin state, contrary to the $\mathrm{Co}(\mathrm{II})$ state. ${ }^{38-40}$ Comprehensive understanding of $\left[\mathrm{Co}\left(\mathrm{NH}_{3}\right)_{6}\right]^{3+}$ and $\left[\mathrm{Co}\left(\mathrm{NH}_{3}\right)_{5} \mathrm{NO}_{2}\right]^{2+}$ isomers requires state-of-the-art quantum chemical methods. All geometries were fully optimized and minima characterized by real vibrational modes at $\omega \mathrm{B} 97 \mathrm{XD} / 6$ $31+\mathrm{G}(\mathrm{d}, \mathrm{p})$. Transition states were located using QST3 and IRC methods, followed by vibrational frequency analysis. All the minima energy values reported here are zero-point energy (ZPE) corrected using the expression:

$$
\Delta E_{\mathrm{ZPE}}=\sum_{i} \frac{1}{2} h v_{i}
$$

where $h$ and $\nu_{i}$ stand for Plank's constant and the vibrational frequency of mode $Q_{i}$, respectively.

$\operatorname{CCSD}(\mathrm{T})$ single-point calculations were performed based on CCSD optimized geometries to validate our methodology, and the structures and their relative energies were found to be similar to those obtained at $\omega \mathrm{B} 97 \mathrm{XD}$. The dynamic correlation in $D_{3 \mathrm{~d}}-\mathrm{Co}\left(\mathrm{NH}_{3}\right)_{6}{ }^{3+}$ was traited on the top of the $\operatorname{CASSCF}(2,2)$ method with the Multireference Averaged Coupled-Pair Functional (MRACPF) approach to evaluate the Pseudo-Jahn-Teller stabilization energy (PJTE). The dispersion energies in the complexes were evaluated as an electronic energy difference between B3LYP and B3LYP-D3. The latter is composed of three terms: Kohn-Sham B3LYP, pair-wise London dispersion and three-body dispersion energies. Several studies ${ }^{\mathbf{4 1 , 4 2}}$ have indicated that transition metals can have important relativistic effects that require detailed research. The zero-order regularized approximation to the Dirac equation (ZORA) ${ }^{42}$ was employed to treat relativistic effects. The symmetry disruption in the $D_{3 \mathrm{~d}}$ $\left[\mathrm{Co}\left(\mathrm{NH}_{3}\right)_{6}\right]^{3+}$ was investigated using quantum mechanical calculations and group theory. ${ }^{43}$ Further, the $D_{3 \mathrm{~d}}$ epikernels of $\left[\mathrm{Co}\left(\mathrm{NH}_{3}\right)_{6}\right]^{3+}$ were compared with $\left[\mathrm{Ru}\left(\mathrm{NH}_{3}\right)_{6}\right]^{3+},\left[\mathrm{Cr}\left(\mathrm{NH}_{3}\right)_{6}\right]^{3+}$ and $\left[\mathrm{Fe}\left(\mathrm{NH}_{3}\right)_{6}\right]^{2+}$ epikernels at B3LYP/LanL2DZ. The accumulation of electron density at the bond critical point (BCP), ${ }^{\mathbf{4}}$ electron localization function (ELF), ${ }^{45,46}$ and natural bond orbitals $(\mathrm{NBO})^{47,48}$ were undertaken to obtain useful information on the electron density charge distribution and for the rationalization of chemical bonding. Most of the optimization calculations were performed using Gaussian $09^{49}$ for single reference methods, whereas orca $^{50}$ program was employed for treatment of multireference and relativistic effects. Further optimization of the epikernels geometries of $\left[\mathrm{Co}\left(\mathrm{NH}_{3}\right)_{6}\right]^{3+}\left(D_{3 \mathrm{~d}}, D_{3}, S_{6}, C_{2 \mathrm{~h}}\right)$ were carried out using B3LYP/TZP on TURBOMOLE ${ }^{51}$ and SVWN/TZP method including ZORA on Amsterdam Density Functional (ADF). ${ }^{52}$ Gaussview 5.0, ${ }^{53}$ chemcraft, ${ }^{54} \mathrm{Jmol} 13.0,{ }^{55}$ were used for visualization while AIM2000, ${ }^{56}$ and Multiwfn ${ }^{57}$ programs were employed to analyze the topology of the chemical bonding in nitro/nitrito linkage isomers.

\section{Results and discussion}

\section{$3.1\left[\mathrm{Co}\left(\mathrm{NH}_{3}\right)_{6}\right]^{3+}$}

3.1.1 Analysis of the structural distortion from $D_{3 \mathrm{~d}}$ to $D_{3}$ symmetry. In $D_{3 \mathrm{~d}}-\left[\mathrm{Co}\left(\mathrm{NH}_{3}\right)_{6}\right]^{3+}$ the $t_{2 \mathrm{u}}\left(t_{2 \mathrm{~g}}\right)$ orbital from octahedral symmetry $\left(O_{\mathrm{h}}\right)$ splits in $e_{\mathrm{u}}$ and $a_{2 \mathrm{u}}\left(e_{\mathrm{g}}\right.$ and $\left.a_{2 \mathrm{~g}}\right)$. The Frontier molecular orbitals of $D_{3 \mathrm{~d}^{-}}\left[\mathrm{Co}\left(\mathrm{NH}_{3}\right)_{6}\right]^{3+}$ are shown in Fig. 2, and the energy levels of valence MOs are listed in Table S1. $\dagger$ The HOMO and LUMO in $D_{3 d^{-}}\left[\mathrm{Co}\left(\mathrm{NH}_{3}\right)_{6}\right]^{3+}$ are on ammonia and belong respectively to $e_{\mathrm{g}}$ and $a_{1 \mathrm{~g}}$ representation. Their energy difference computed is nearly $11.11 \mathrm{eV}$ at $\omega \mathrm{B} 97 \mathrm{XD}$, 13.25 $\mathrm{eV}$ at LC-BLYP and 17.74 eV at MP2 (17.70 eV at CCSD(T)/ 6-31+G(d,p)). LC-BLYP, and $\omega$ B97XD methods have tendency to underestimate the HOMO-LUMO gaps compare to MP2 method. LC-BLYP, $\omega$ B97XD, and MP2 methods yield Co-N bonds distances of 1.97-2.01 $\AA$ close to CCSD and $\mathrm{BD}(\mathrm{T})$ bond lengths calculated about 1.99-2.00 $\AA$ in gas phase (Table 1$)$. The experimental value of the equilibrium $\mathrm{Co}-\mathrm{N}$ bond length of $\mathrm{Co}\left(\mathrm{NH}_{3}\right)_{6}{ }^{3+}$ is measured and found to be around $1.97 \AA_{;} ;^{58-60}$ this is not significantly different from CCSD/6-31+G(d,p) calculated bond in the gas phase. This small difference between experiment and calculated bond distance is explained by different environment of $\left[\mathrm{Co}\left(\mathrm{NH}_{3}\right)_{6}\right]^{3+}$ in solid. It has been reported in solution that the neglect of solvent-solute charge transfer effect can yield too long Co-N bond lengths. ${ }^{61}$

Our calculations show that $D_{3 \mathrm{~d}}$ in vacuo is unstable contrary to what was reported elsewhere, ${ }^{3}$ in solid and aqueous media. Its optimized geometry is characterized by six imaginary modes of representations $a_{1 \mathrm{u}}, a_{2 \mathrm{~g}}, e_{\mathrm{g}}$ and $e_{\mathrm{u}}$ at i167, i164, i101 and i90 $\mathrm{cm}^{-1}$ at $\omega \mathrm{B} 97 \mathrm{XD} / 6-31+\mathrm{G}(\mathrm{d}, \mathrm{p})\left(\mathrm{i} 154, \mathrm{i} 150, \mathrm{i} 74\right.$ and $\mathrm{i} 45 \mathrm{~cm}^{-1}$ at 


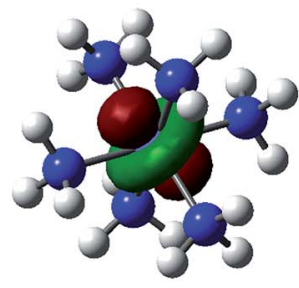

HOMO-1 $\left(\mathrm{a}_{1 \mathrm{~g}}\right)$

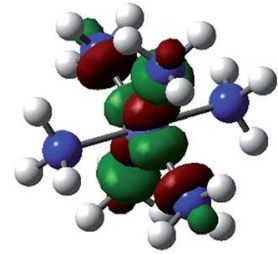

$\operatorname{LUMO}\left(\mathrm{e}_{\mathrm{g}}\right)$

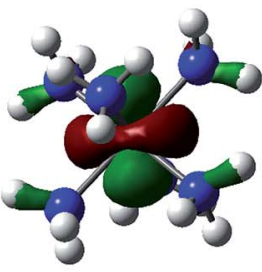

$\operatorname{HOMO}\left(\mathrm{e}_{\mathrm{g}}\right)$

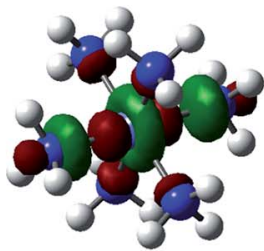

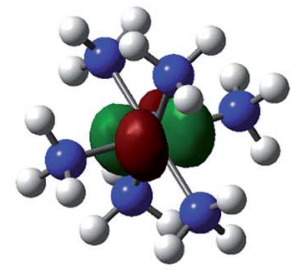

$\operatorname{HOMO}\left(\mathrm{e}_{\mathrm{g}}\right)$

Fig. 2 The Frontier molecular orbitals of $D_{3 d}-\left[\mathrm{Co}\left(\mathrm{NH}_{3}\right)_{6}\right]^{3+}$ computed at $\omega \mathrm{B} 97 \mathrm{XD} / 6-31+\mathrm{G}(\mathrm{d}, \mathrm{p})$.

CCSD/6-31G(d)), respectively. A distortion with the $D_{3}$ symmetry constraint yields a minimum energy characterized by the lowest vibrational mode of $e$ symmetry located at $89 \mathrm{~cm}^{-1}$ at $\omega \mathrm{B} 97 \mathrm{XD} / 6-$ $31+\mathrm{G}(\mathrm{d}, \mathrm{p})\left(79 \mathrm{~cm}^{-1}\right.$ at $\left.\mathrm{CCSD} / 6-31 \mathrm{G}(\mathrm{d})\right)$. The energy difference between the HOMO and LUMO is slightly increased to $17.74 \mathrm{eV}$ at $\operatorname{CCSD}(\mathrm{T}) / 6-31+\mathrm{G}(\mathrm{d}, \mathrm{p})$ for $D_{3}$. A further optimization of $D_{3}$ and $D_{3 \mathrm{~d}}$ geometries using B3LYP/TZP method as implemented in TURBOMOLE gives an energy difference of $1.54 \mathrm{kcal} \mathrm{mol}^{-1}$. The HOMO-LUMO gap in gas phase is $6.25 \mathrm{eV}$. The vibrational analysis is characterized by two imaginary frequency at i107.97 and i104.40 $\mathrm{cm}^{-1}$ of $a_{1 \mathrm{u}}$ and $a_{2 \mathrm{~g}}$ representations, whereas a full optimization of the same geometry in $D_{3 \mathrm{~d}}$ at the SVWN/TZP including the scalar and spin-orbit ZORA as implemented in ADF program reproduces six imaginary frequencies estimated about i137.99 $\left(a_{1 \mathrm{u}}\right)$, i137.90 $\left(a_{2 \mathrm{~g}}\right)$, i54.56 $\left(e_{\mathrm{g}}\right)$, i18.00 $\left(e_{\mathrm{u}}\right) \mathrm{cm}^{-1}$ confirming that $D_{3 \mathrm{~d}}$ is not the true global minimum of $\left[\mathrm{Co}\left(\mathrm{NH}_{3}\right)_{6}\right]^{3+}$.

The structural change between $D_{3 \mathrm{~d}}$ and $D_{3}$ in $\left[\mathrm{Co}\left(\mathrm{NH}_{3}\right)_{6}\right]^{3+}$ is small (Fig. S2 $\dagger$ ). The distortion vector responsible of this symmetry breaking can be expressed as: $:^{62,63}$

Table 1 Co-N bonds in $\AA$, HOMO-LUMO (H-L) gap energies in eV, lowest vibrational frequencies (LF) in $\mathrm{cm}^{-1}$ and PJT stabilization energies in $\mathrm{kcal} \mathrm{mol}^{-1}$ of $D_{3}-\left[\mathrm{Co}\left(\mathrm{NH}_{3}\right)_{6}\right]^{3+}$ computed using different methods in conjunction with $6-31+G(d, p)$

\begin{tabular}{lllll}
\hline Methods & Co-N & PJT energy & H-L gaps & LF (symmetry) \\
\hline BD(T) & 2.001 & 2.16 & 17.24 & - \\
CCSD(T) & 1.992 & 2.14 & 17.74 & - \\
MP2 & 1.973 & 2.43 & 17.79 & - \\
B3LYP & 2.013 & 1.75 & 6.28 & $75(\mathrm{e})$ \\
B3LYP-D3 & 2.004 & 1.77 & 6.24 & $78(\mathrm{e})$ \\
M062X & 2.022 & 2.04 & 10.89 & $106(\mathrm{e})$ \\
wB97XD & 2.009 & 2.12 & 11.13 & $89(\mathrm{e})$ \\
LC-BLYP & 1.976 & 2.14 & 13.27 & $83(\mathrm{e})$ \\
Exp. [ref. 55] & 1.97 & & &
\end{tabular}

$$
\vec{\Delta}_{D_{3 \mathrm{~d}}-D_{3}}=\sum_{i, j} C_{\Gamma_{j}{ }^{i}} \vec{Q}_{\Gamma_{j}{ }^{i}}
$$

where the coefficient in the expression is related to the weight of the imaginary mode $\vec{Q}_{\Gamma_{j}^{i}}$, and the subscript describes the irreducible representation of the vibrational mode.

Our calculations show a significant contribution of the $1 a_{1 \mathrm{u}}$ imaginary mode of nearly $98.89 \%$ in the distortion vector (Fig. S3 $\dagger$ ). A further distortion of $D_{3 \mathrm{~d}}$ along the imaginary vibrational mode $a_{2 \mathrm{~g}}$ will lead to $S_{6}$. The distortion of $D_{3 \mathrm{~d}^{-}}$ $\left[\mathrm{Co}\left(\mathrm{NH}_{3}\right)_{6}\right]^{3+}$ along $1 a_{1 \mathrm{u}}$ vibrational mode acts essentially on $\mathrm{H}$ and destroys the center of symmetry. The full $D_{3 \mathrm{~d}}$ symmetry group is broken because by destroying the inversion point, $1 a_{1 \mathrm{u}}$ will also remove the improper rotation axis $\left(S_{6}\right)$ and the dihedral plane. However, the imaginary modes show a rotation of hydrogen atoms. The free rotation of $\mathrm{NH}_{3}$ groups in octahedral symmetry observed in water solvent should not strictly be applicable to low symmetry complex. The decent in symmetry observed from $D_{3 \mathrm{~d}}$ to its subgroup $D_{3}$ can only arise from the Pseudo-Jahn-Teller (PJT) effect because the HOMO $\left(e_{\mathrm{g}}\right)^{4}$ in $D_{3 \mathrm{~d}}$ is fully occupied and cannot trigger a pure Jahn-Teller distortion according to group theory. The computed PJT energy caused by this vibronic coupling is about $742 \mathrm{~cm}^{-1}$ at $\omega \mathrm{B} 97 \mathrm{XD} /$ $6-31+\mathrm{G}(\mathrm{d}, \mathrm{p})\left(\sim 750 \mathrm{~cm}^{-1}\right.$ at $\left.\operatorname{CCSD}(\mathrm{T}) / 6-31+\mathrm{G}(\mathrm{d}, \mathrm{p})\right)$. The Pseudo-

Table $2 \mathrm{M}-\mathrm{N}$ distances (with $\mathrm{M}$ transition metal), pseudo-Jahn-Teller energies $\left(\mathrm{cm}^{-1}\right)$ and lowest real frequencies computed at B3LYP/ LanL2DZ of $D_{3}$ and $S_{6}$ in parenthesis of $\left[\mathrm{Co}\left(\mathrm{NH}_{3}\right)_{6}\right]^{3+}$, $\left[\mathrm{Ru}\left(\mathrm{NH}_{3}\right)_{6}\right]^{3+}$, $\left[\mathrm{Cr}\left(\mathrm{NH}_{3}\right)_{6}\right]^{3+}$ and $\left[\mathrm{Fe}\left(\mathrm{NH}_{3}\right)_{6}\right]^{2+}$ at B3LYP/LanL2DZ

\begin{tabular}{|c|c|c|c|c|c|}
\hline & State & $\mathrm{M}-\mathrm{N}$ & Ref. & PJTE & LF \\
\hline Co & ${ }^{1} \mathrm{~A}_{1 \mathrm{~g}}$ & 2.037 & $2.014,{ }^{61} 2034,{ }^{61} 2.009,{ }^{67} 1.967^{58}$ & 749 (596) & $94(48)$ \\
\hline $\mathrm{Ru}$ & ${ }^{2} \mathrm{~A}_{1 \mathrm{~g}}$ & 2.193 & $2.104,^{68} 2.113^{67}$ & $209(237)$ & $56(56)$ \\
\hline $\mathrm{Cr}$ & ${ }^{4} \mathrm{~A}_{1 \mathrm{~g}}$ & 2.149 & $2.060^{69}$ & $594(463)$ & $75(55)$ \\
\hline $\mathrm{Fe}$ & ${ }^{5} \mathrm{~A}_{1 \mathrm{~g}}$ & 2.295 & $2.293,,^{70} 2.21^{71}$ & $167(101)$ & $38(41)$ \\
\hline
\end{tabular}


Table 3 Number and symmetry of imaginary modes in $C_{2 h}$ and $D_{3 d}$ optimized geometries computed at B3LYP/LanL2dz and relative energies in $\mathrm{kcal} \mathrm{mol}^{-1}$ with respect to $D_{3 \mathrm{~d}}$ geometry

\begin{tabular}{|c|c|c|c|}
\hline State in $D_{3 \mathrm{~d}}$ & $C_{2 \mathrm{~h}}$ & $D_{3 \mathrm{~d}}$ & $\mathrm{RE}$ \\
\hline $\mathrm{Co}\left[{ }^{1} \mathrm{~A}_{1 \mathrm{~g}}\right]$ & $i 70\left(a_{u}\right), i 50\left(b_{g}\right)$ & i160( $\left.\mathrm{a}_{1 \mathrm{u}}\right), \mathrm{i} 155\left(\mathrm{a}_{2 \mathrm{~g}}\right), \mathrm{i} 77\left(\mathrm{e}_{\mathrm{g}}\right), \mathrm{i} 36\left(\mathrm{e}_{\mathrm{u}}\right)$ & -1.60 \\
\hline $\mathrm{Ru}\left[{ }^{2} \mathrm{~A}_{1 \mathrm{~g}}\right]$ & $\mathrm{i} 52\left(\mathrm{a}_{\mathrm{u}}\right), \mathrm{i} 48\left(\mathrm{~b}_{\mathrm{g}}\right)$ & $\mathrm{i} 106\left(\mathrm{a}_{2 \mathrm{~g}}\right), \mathrm{i} 98\left(\mathrm{a}_{1 \mathrm{u}}\right), \mathrm{i} 23\left(\mathrm{e}_{\mathrm{g}}\right)$ & 0.05 \\
\hline $\operatorname{Fe}\left[{ }^{5} A_{1 g}\right]$ & $\mathrm{i} 51\left(\mathrm{e}_{\mathrm{u}}\right)$ & $\mathrm{i} 80\left(\mathrm{a}_{1 \mathrm{u}}\right), \mathrm{i} 67\left(\mathrm{a}_{2 \mathrm{~g}}\right)$ & -0.33 \\
\hline
\end{tabular}

Jahn-Teller computed at CASSCF(2,2)-MRCAPF/SVP is about $154 \mathrm{~cm}^{-1}$ at SVP. Krisloff et al. ${ }^{64}$ investigated the unphysical ground states of the multireference averaged coupled-pair functional and reported that $\operatorname{CASSCF}(2,2)-\mathrm{MRCAPF}$ can provide unphysical solution in the avoided crossing or conical intersection and the instabilities can be removed by employing larger complete active spaces (CAS). Unfortunately, the latter is computationally more demanding. The molecular orbitals involved in this distortion mechanism require further investigation. The energy level of the valence molecular orbitals of the $D_{3 \mathrm{~d}}$ geometry is listed in Table S1† and agree with the literature $^{65}$ The HOMOs are localized on the metal and are nonbonding pure d orbitals. The LUMOs have high contribution on the metal and nitrogen and are antibonding orbitals (Fig. S1 $\dagger)$. The HOMO $\left(e_{\mathrm{g}}\right)$ and HOMO-1 $\left(a_{1 \mathrm{~g}}\right)$ derived from the reduction of $t_{2 \mathrm{~g}}$ in $O_{\mathrm{h}}$. To validate the use of $\omega \mathrm{B} 97 \mathrm{XD}$, various DFT and MP2 methods were employed and compared with $\operatorname{CCSD}(\mathrm{T})$. The data obtained shown in Table 1 suggest $\omega \mathrm{B} 97 \mathrm{XD}$ and LC-BLYP could perform quite well with respect to $\operatorname{CCSD}(\mathrm{T})$. Therefore, the $\omega \mathrm{B} 97 \mathrm{XD} / 6-31+\mathrm{G}(\mathrm{d}, \mathrm{p})$ method and the lowest $D_{3}$ geometry are considered for further analysis on nitro-/nitritopentaamminecobalt(III) linkage isomers.

We have extended this study to other hexammines complexes analogs of $\mathrm{Ru}(\mathrm{III}), \mathrm{Cr}(\mathrm{III})$ and $\mathrm{Fe}(\mathrm{II})$ which were reported to have either $D_{3 \mathrm{~d}}$ or $D_{3}$ symmetries..$^{3,58,65-74}\left[\mathrm{Ru}\left(\mathrm{NH}_{3}\right)_{6}\right]^{3+}$, $\left[\mathrm{Cr}\left(\mathrm{NH}_{3}\right)_{6}\right]^{3+}$ and $\left[\mathrm{Fe}\left(\mathrm{NH}_{3}\right)_{6}\right]^{2+}$ ions can be considered as octahedral in which the d orbital of the transition metal splits in $t_{2 \mathrm{~g}}$ and $e_{\mathrm{g}}$. For comparison, the most popular functional for transition metal B3LYP was employed with LanL2DZ basis set for all atoms on the $D_{3 \mathrm{~d}}$ symmetry of the low-spin states $\left[{ }^{1} A_{1 \mathrm{~g}}:\left(t_{2 \mathrm{~g}}\right)^{6}\right.$ $\left.\left(e_{\mathrm{g}}\right)^{0}\right]$ and $\left[{ }^{2} T_{2 \mathrm{~g}}:\left(t_{2 \mathrm{~g}}\right)^{5}\left(e_{\mathrm{g}}\right)^{0}\right]$ of $\left[\mathrm{Co}\left(\mathrm{NH}_{3}\right)_{6}\right]^{3+}$ and $\left[\mathrm{Ru}\left(\mathrm{NH}_{3}\right)_{6}\right]^{3+}$, and high spin states $\left[{ }^{4} T_{2 \mathrm{~g}}:\left(t_{2 \mathrm{~g}}\right)^{3}\left(e_{\mathrm{g} g}\right)^{0}\right]$ and $\left[{ }^{5} T_{2 \mathrm{~g}}:\left(t_{2 \mathrm{~g}}\right)^{4}\left(e_{\mathrm{g}}\right)^{2}\right]$ of $\left[\mathrm{Cr}\left(\mathrm{NH}_{3}\right)_{6}\right]^{3+}$ and $\left[\mathrm{Fe}\left(\mathrm{NH}_{3}\right)_{6}\right]^{2+}$. The Pseudo-Jahn-Teller energies obtained at B3LYP/LanL2DZ for the symmetry breaking of $D_{3 \mathrm{~d}}$ towards either $D_{3}$ or $S_{6}$ are given in Table 2. $D_{3}$ and $S_{6}$ are higher ranking epikernels and are found as minima for all transition metal complexes studied in the present paper, whereas the lower ranking epikernel $C_{2 \mathrm{~h}}$ is found to be a saddle point [Tables 2 and 3]. The difference in metal-N bonds between $D_{3}$ and $S_{6}$ is negligible $(\sim 0.001 \mathrm{~A})$. These findings are in good agreement with the epikernel principle. ${ }^{63}$ The Pseudo-JahnTeller distortion energies are considerably more important in Co- and Cr-complexes than Ru- and Fe-complexes. The M-N bonds distances listed in Table 2 computed at B3LYP/LanL2DZ are close to that obtained at high level of calculations..$^{61,67-71}$ For instance, the $\mathrm{Co}-\mathrm{N}$ bond evaluated about 2.037 at B3LYP/ LanL2DZ is approaching that obtained by Rotzinger ${ }^{61}$ at CASSF-MP2(10,10)/6-31G(d) and CASSF(10,10)/6-31G(d) levels, estimated about 2.014 and 2.034. The $D_{3}\left[\mathrm{Fe}\left(\mathrm{NH}_{3}\right)_{6}\right]^{2+}$ geometry was also predicted as minima by Pierloot et al. ${ }^{70}$ in their study on the performance of BP86, B3LYP and PBE0 with CASPT2 in the estimation of the relative energy of the high and low spins states of $\left[\mathrm{Fe}\left(\mathrm{H}_{2} \mathrm{O}\right)_{6}\right]^{2+},\left[\mathrm{Fe}\left(\mathrm{NH}_{3}\right)_{6}\right]^{2+}$ and $\left[\mathrm{Fe}(\mathrm{bpy})_{3}\right]^{2+}$. According to the authors, DFT even in cases it does not provide accurate energetics, still provides high quality structure.

Contrary to $D_{3}$ symmetry which symmetry was mentioned by many researchers, ${ }^{61,70} S_{6}$ symmetry is proposed in the present paper for the first time as probable minima for $\left[\mathrm{Co}\left(\mathrm{NH}_{3}\right)_{6}\right]^{3+}$, $\left[\mathrm{Cr}\left(\mathrm{NH}_{3}\right)_{6}\right]^{3+},\left[\mathrm{Ru}\left(\mathrm{NH}_{3}\right)_{6}\right]^{3+}$ and $\left[\mathrm{Fe}\left(\mathrm{NH}_{3}\right)_{6}\right]^{2+}$ in gas phase. Tables S2 and S3 $\uparrow$ compare B3LYP, $\omega$ B97XD and OPBE results of $\left[\mathrm{Co}(\mathrm{NH})_{3}\right]_{6}{ }^{3+}$ computed with ccpVtz basis sets to check the basis set dependency. The OPBE functional was suggested by Swart et $a l^{72}$ to provide accurate geometries for several transition metal compounds. The relative energies of $D_{3}, S_{6}$ and $C_{2 \mathrm{~h}}$ with respect to $D_{3 \mathrm{~d}}$ computed with OPBE method lay in between $\omega$ B97XD and B3LYP. $D_{3}$ is slightly more stable than $S_{6}$ at different levels of calculations. The EOMCCSD/6-31+G(d,p) calculations from $D_{3}$ optimized geometry show three bands at 114,129 , and $162 \mathrm{~nm}$ assigned to respectively ligand to ligand transition $\left(4 t_{1 \mathrm{u}} \rightarrow 5 a_{1 \mathrm{~g}}\right)$, and ligand to metal charge transfer transitions $\left(1 a_{1 \mathrm{u}} \rightarrow 5 e_{\mathrm{g}}\right.$ and $\left.4 t_{1 \mathrm{u}} \rightarrow 5 e_{\mathrm{g}}\right)$ which lie close to the greatest absorbance experimental value of about $195 \mathrm{~nm}$ reported by Goursot et al. ${ }^{65}$ They argue that the ab initio energy values of these charge transfer transitions are largely dependent on the basis set chosen. A similar transition was observed in $\left[\mathrm{Ru}\left(\mathrm{NH}_{3}\right)_{6}\right]^{3+} \mathrm{UV}$-vis spectrum also arising from $t_{1 \mathrm{u}}$ and $e_{\mathrm{g} \cdot{ }^{73,74}}$ Daul et al. ${ }^{74}$ investigated the electronic structure of $\left[\mathrm{Ru}\left(\mathrm{NH}_{3}\right)_{6}\right]^{3+}$ using extended Huckel molecular orbitals method and reported that ammonia are rotating freely to keep an octahedral site symmetry. The d-d transitions in octahedral $\left[\mathrm{Co}\left(\mathrm{NH}_{3}\right)_{6}\right]^{3+}$ and $\left[\mathrm{Ru}\left(\mathrm{NH}_{3}\right)_{6}\right]^{3+}$ complexes are forbidden due to the presence of a center of inversion following Laporte rule ${ }^{75}$ which states that allowed transitions in centro-symmetric molecules should involve change in parity between gerade and ungerade orbitals. In real world, $\left[\mathrm{Co}\left(\mathrm{NH}_{3}\right)_{6}\right]^{3+}$ and $\left[\mathrm{Ru}\left(\mathrm{NH}_{3}\right)_{6}\right]^{3+}$ geometries are not frozen but thermally vibrating. The oscillator strength of the symmetry-forbidden $\mathrm{d}-\mathrm{d}$ transition of the octahedral transition metal complexes, $\left[\mathrm{Co}\left(\mathrm{NH}_{3}\right)_{6}\right]^{3+}$ and $\left[\mathrm{Ru}\left(\mathrm{NH}_{3}\right)_{6}\right]^{3+}$, was evaluated theoretically by Saito et al. ${ }^{67}$ using B3PW91 functional with the effective core potential/basis set combination SDB-cc-pVTZ. The authors found that the oscillator strengths of ${ }^{1} A_{1} \rightarrow{ }^{1} T_{1 g}$ is considerably larger than that of the ${ }^{1} A_{1 g} \rightarrow{ }^{1} T_{2 g}$ in both complexes and arises from $\mathrm{H}_{3} \mathrm{~N}-\mathrm{M}-\mathrm{NH}_{3}$ antisymmetric bending vibration. The metal ligand charge transfer (MLCT) was found larger in the Ru-complex than in its counterpart Cocomplex. Multiconfigurational self-consistent-field (MCSCF) 
approaches are more efficient way one can use for diagnosticate the pseudo-Janh-Teller effect in $D_{3 \mathrm{~d}^{-}}\left[\mathrm{M}\left(\mathrm{NH}_{3}\right)_{6}\right]^{3+}$ (with $\mathrm{M}=\mathrm{Co}$, $\mathrm{Fe}, \mathrm{Cr}, \mathrm{Ru}) .^{76}$ Symmetry plays a crucial role in Physics and Chemistry because the properties of molecular systems under symmetry transformation govern selection rules for molecular spectroscopy and interactions. ${ }^{77}$

\section{$3.2\left[\mathrm{Co}\left(\mathrm{NH}_{3}\right)_{5} \mathrm{NO}_{2}\right]^{2+}$ and $\left[\mathrm{Co}\left(\mathrm{NH}_{3}\right)_{5} \mathrm{ONO}\right]^{2+}$}

\subsubsection{Geometries}

Geometries of $\left[\mathrm{Co}-\mathrm{NO}_{2}\right]^{2+}$ and $[\mathrm{Co}-\mathrm{ONO}]^{2+}$ isomer compared to $\mathrm{D}_{3}-\left[\mathrm{Co}\left(\mathrm{NH}_{3}\right)_{6}\right]^{3+}$. Fig. 3 shows the geometries of the ground states of $O$ - and $N$-linked isomers and transition states computed at $\omega \mathrm{B} 97 \mathrm{XD} / 6-31+\mathrm{G}(\mathrm{d}, \mathrm{p})$. A close inspection on the geometric structures shows that the substitution of ammonia by nitro or nitrito in $\left[\mathrm{Co}\left(\mathrm{NH}_{3}\right)_{6}\right]^{3+}$ to form $\left[\mathrm{Co}\left(\mathrm{NH}_{3}\right)_{5} \mathrm{NO}_{2}\right]^{2+}$ or $\left[\mathrm{Co}\left(\mathrm{NH}_{3}\right)_{5} \mathrm{ONO}_{2}\right]^{2+}$ gives rise to the shrinking of Co-N bonds formed by $\mathrm{NH}_{3}$ positioned in the equatorial region with the concomitant elongation of the axial Co- $\mathrm{NH}_{3}$ bond. The $\mathrm{NH}_{3}$ ligands in the horizontal plane are apparently more strongly bound to Co than the axial $\mathrm{NH}_{3}$ ligands. In $\mathrm{Co}-\mathrm{NO}_{2}$ (Fig. 3a), the bond length between Co and $\mathrm{NO}_{2}$ is $1.924 \AA$, which is 0.075 and $0.141 \AA$ shorter than those in the Co-N bonds formed by equatorial and axial $\mathrm{NH}_{3}$. The Co-O bond length in the exo-ONO complex (Fig. 3b) is $\sim 0.03 \AA$ shorter than that of the endo-ONO

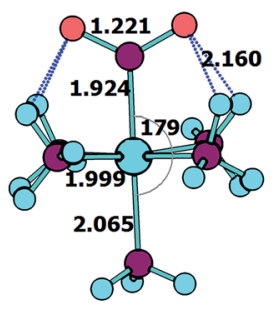

(a)

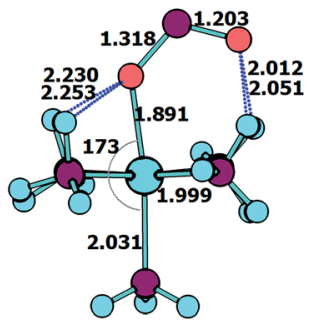

(c)

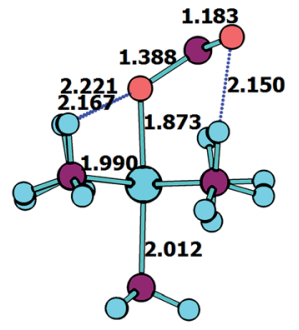

(e)TS2 (endo-Co-ONO_exo-Co-ONO)

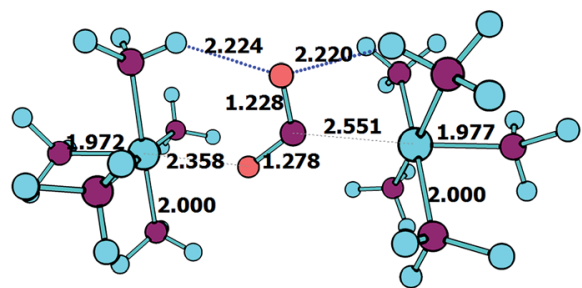

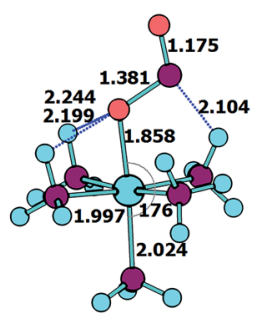

(b)

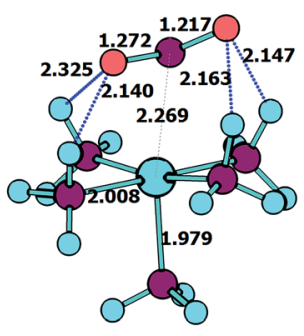

(d) TS1 (Co-NO2_endo-Co-ONO)

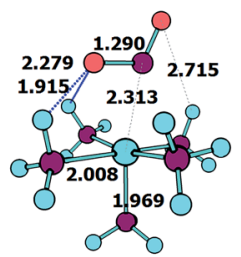

(f)TS3 $\left(\mathrm{Co}-\mathrm{NO}_{2}\right.$ exo-Co-ONO)

(g) TS4

Fig. 3 Equilibrium geometries $(\mathrm{a}-\mathrm{c})$ and transition states geometries $(\mathrm{d}-\mathrm{g})$ of $\mathrm{Co}\left(\mathrm{NH}_{3}\right)_{5} \mathrm{NO}_{2}{ }^{2+}$ and $\mathrm{Co}\left(\mathrm{NH}_{3}\right)_{5} \mathrm{ONO}{ }^{2+}$ isomers computed at $\omega B 97 X D / 6-31+G(d, p)$. 


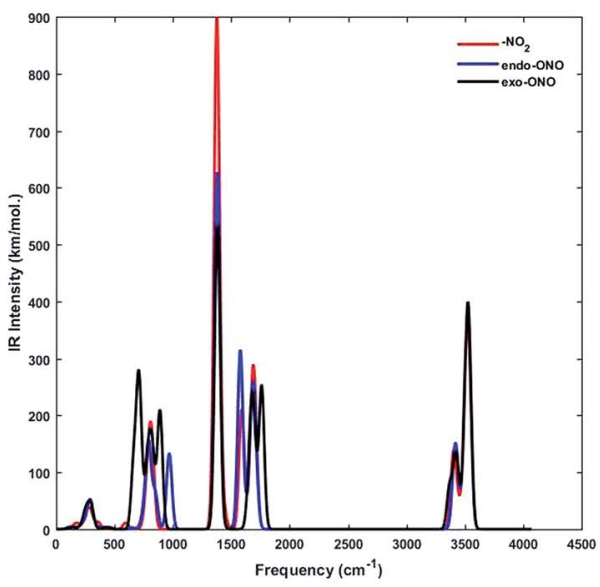

(a)

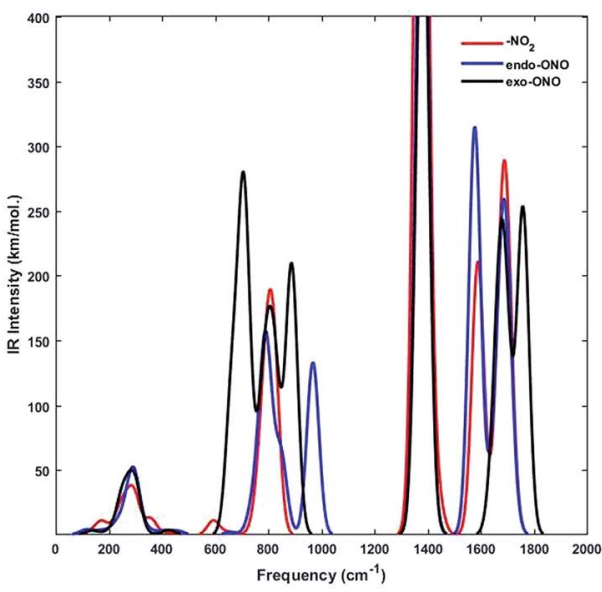

(b)

Fig. 4 Superimposed IR spectra of $\mathrm{Co}-\mathrm{NO}_{2}$ and $\mathrm{Co}-\mathrm{ONO}$ complexes computed using a scaling factor of 0.9632 at B3LYP/6-31+G(d,p).

complex (Fig. 3c). The Co- $\mathrm{NO}_{2}$ and exo-Co-ONO geometries were also studied by Ciofini et al. ${ }^{33}$ at B3LYP/LanL2DZ level in order to clarify the intrinsic and environmental effects on the kinetic and thermodynamics of linkage isomerizasion in nitropentaamminecobalt(III) complex. The geometrical parameters of our $\mathrm{Co}-\mathrm{NO}_{2}$ and $\mathrm{Co}-\mathrm{ONO}$ complexes optimized at $\omega \mathrm{B} 97 \mathrm{XD} / 6-31+\mathrm{G}(\mathrm{d}, \mathrm{p})$ are compared in Table S4† with B3LYP/ Lanl2dz geometries obtained by Ciofini et al. ${ }^{33}$ and the available X-ray data. ${ }^{78,79} \omega \mathrm{B} 97 \mathrm{XD} / 6-31+\mathrm{G}(\mathrm{d}, \mathrm{p})$ performs better than B3LYP/Lanl2dz and the small difference observed between X-ray and the optimized geometries can be attributed to crystal environment. ${ }^{33}$ Boldyreva et al. $^{80}$ found different geometrical parameters in the pentaamminenitrocobalt(III)chloride nitrate at $298 \mathrm{~K}$ and $150 \mathrm{~K}$ using X-ray spectroscopy characterized by $\mathrm{Co}-\mathrm{N}$, and $\mathrm{N}-\mathrm{O}$ distances in the range of 1.959-1.989 and 1.2061.222, and $\mathrm{O}-\mathrm{N}-\mathrm{O}$ and $\mathrm{O}-\mathrm{N}-\mathrm{Co}$ bonds angles of 123.1 and 117.8 degrees.

All these $\omega \mathrm{B} 97 \mathrm{XD} / 6-31+\mathrm{G}(\mathrm{d}, \mathrm{p})$ optimized geometries comprise intramolecular hydrogen bonding (IHB) involving $\mathrm{NO}_{2}$ or ONO. The Co- $\mathrm{NO}_{2}$ complex has a $\mathrm{O} \cdots \mathrm{H}-\mathrm{N}$ bond of 2.160 $\AA$, which is $0.148 \AA$ longer than the shortest $\mathrm{O} \cdots \mathrm{H}-\mathrm{N}$ bond in the endo-Co-ONO complex. The exo-Co-ONO is characterized by two types of IHBs: $\mathrm{N} \cdots \mathrm{H}-\mathrm{N}$ and $\mathrm{O} \cdots \mathrm{H}-\mathrm{N}$ of 2.104 and 2.199$2.244 \AA$. The two $\mathrm{N}-\mathrm{O}$ bonds that have the same bond lengths in the nitro-complex becomes unequal when the nitro is orientated in nitrito, and the difference between the bond lengths increases from the endo-nitrito to exo-nitrito complex, showing a decrease in the electron resonance character of the ONO atoms group. Electron delocalization around $\mathrm{ONO}$ was reported $^{\mathbf{8 1}}$ to enhance hydrogen bonds.

We have computed the IR spectra of nitro and nitrito complexes at B3LYP/6-31+G(d,p). Our calculations show a clear difference in vibrational frequencies between $\mathrm{NO}_{2}$ and ONO isomers in the region between $700-1700 \mathrm{~cm}^{-1}$ (Fig. 4). The vibrational modes which characterize the $\mathrm{NO}_{2}$ and $\mathrm{ONO}$ in Co$\mathrm{NO}_{2}$ and Co-ONO complexes are listed in Table 4 and shown in Fig. 5. The deformation $\mathrm{NO}_{2}$ and ONO modes are well reproduced whereas our asymmetric $\mathrm{N}-\mathrm{O}$ stretching modes are overestimated referring to Ciofini findings and experimental data. $^{33}$

Transition states. $\mathrm{Co}-\mathrm{NO}_{2} \rightarrow$ endo-Co-ONO $\rightarrow$ exo-Co-ONO reaction mechanism describes the sequence of the elementary transformation of Co- $\mathrm{NO}_{2}$ complex in exo-Co-ONO via the endoCo-ONO complex. TS1 (i569 $\mathrm{cm}^{-1}$ computed at $\omega \mathrm{B} 97 \mathrm{XD} / 6-$ $31+\mathrm{G}(\mathrm{d}, \mathrm{p}))$ and TS2 (i210 $\left.\mathrm{cm}^{-1} \omega \mathrm{B} 97 \mathrm{XD} / 6-31+\mathrm{G}(\mathrm{d}, \mathrm{p})\right)$ depicted in Fig. 3d and e are predicted sequential transition states in this reaction path by intrinsic reaction coordinate (IRC) method. TS1 has a $\mathrm{NO}_{2}$ moiety detached from Co; the Co-N bond length is estimated to be about $2.27 \AA$, but still binds to four $\mathrm{NH}_{3}$ ligands through $\mathrm{O} \cdots \mathrm{H}-\mathrm{N}$ hydrogen bonds ranging between 2.14 and $2.32 \AA$ at $\omega \mathrm{B} 97 \mathrm{XD} / 6-31+\mathrm{G}(\mathrm{d}, \mathrm{p})$. The TS1 geometry was reported as first-order saddle point with one imaginary vibrational mode located at i385 $\mathrm{cm}^{-1}$ at B3LYP/LanL2DZ. ${ }^{33}$ Its geometrical parameters geometry computed at $\omega \mathrm{B} 97 \mathrm{XD} / 6$ $31+\mathrm{G}(\mathrm{d}, \mathrm{p})$ and B3LYP/LanL2DZ are detailed in Table S4. $\uparrow$ This transition state is difficult to detect experimentally. ${ }^{15}$ The

Table 4 Harmonic vibrational frequencies $\left(\mathrm{cm}^{-1}\right)$ computed at B3LYP/6-31+G(d,p) of Co-NO $\mathrm{N}_{2}$ and Co-ONO isomers

\begin{tabular}{llll}
\hline $\mathrm{Co}-\mathrm{NO}_{2}$ & Endo-Co & Exo-Co-ONO & Assignment \\
\hline $820\left(757^{a}, 825^{b}\right)$ & & $880\left(718^{a}, 791^{b}\right)$ & $\mathrm{NO}_{2}$ and ONO deformation \\
$1367\left(1257^{a}, 1315^{b}\right)$ & 968 & & ${\text { Sym. } \mathrm{NO}_{2} \text { stretching }+\mathrm{NH}_{3} \text { defor. }}^{a}$ \\
$1590\left(1466^{a}, 1440^{b}\right)$ & 1578 & $1759\left(1586^{a}, 1460^{b}\right)$ & Asym. $\mathrm{NO}_{2}$ and ONO stretching
\end{tabular}

${ }^{a}$ Theoretical values taken from ref. 33a. ${ }^{b}$ Experimental data taken from ref. 33b. 
structural geometry of TS2 (Co-O bond of $1.87 \AA$ ) is similar to that of exo-Co-ONO but differs with exo-Co-ONO by the orientation of $\mathrm{N}-\mathrm{O}$ bonds, which lies in the horizontal plane to form $\mathrm{N}-\mathrm{O} \cdots \mathrm{H}$ hydrogen bonds of $2.15 \AA$ with ammonia computed at $\omega \mathrm{B} 97 \mathrm{XD} / 6-31+\mathrm{G}(\mathrm{d}, \mathrm{p})$. Another transition state similar to TS1, denoted as TS3 (i506 $\mathrm{cm}^{-1}$ ) (Fig. 3f) was observed between $\mathrm{Co}-\mathrm{NO}_{2}$ and exo-Co-ONO and was characterized by two $\mathrm{O} \cdots \mathrm{H}-\mathrm{N}$ hydrogen bonds of 1.91 and $2.28 \AA$ carried out at $\omega \mathrm{B} 97 \mathrm{XD} / 6-31+\mathrm{G}(\mathrm{d}, \mathrm{p})$. The $\mathrm{N}-\mathrm{O}(1.29 \mathrm{E})$ and $\mathrm{N}-$ Co (2.31 E) bonds in TS3 are slightly longer than that of TS1. The $\pi$-bonding coordination to the central metal observed in these activated complexes (TS1, TS3) was also suggested by Balt et al., ${ }^{82}$ but the authors did not provide the geometries of transition states. The imaginary vibrational modes of these transitions states are shown in Fig. S4. $\dagger$ The displacements of atoms displayed in Fig. $\mathrm{S} 4 \uparrow$ indicate that the imaginary modes of TS1 and TS2 change the Co-O-N-O torsion angle and $\mathrm{O}-\mathrm{N}-\mathrm{O}$ bond angle, whereas in TS3, the imaginary frequency attempts to rotate $\mathrm{NO}_{2}$ atoms group. The change in TS3 between $\mathrm{Co}-\mathrm{NO}_{2}$ and exo-Co-ONO is mediated when the nitro atoms group rotates such that $\mathrm{N}$ or $\mathrm{O}$ can form the $\mathrm{Co}-\mathrm{N}$ or Co-O bond, respectively. TS4 represented in Fig. $3 \mathrm{~g}\left(\mathrm{i} 95 \mathrm{~cm}^{-1}\right)$ was proposed in ref. 83 and 84 as the activated complex to explain the nitro and nitrito interconversion in $\left[\mathrm{Co}\left(\mathrm{NH}_{3}\right)_{5} \mathrm{NO}_{2}\right]$ $\mathrm{NO}_{3} \mathrm{Cl}$ through the intermolecular process. In TS4, two groups of $\mathrm{Co}\left(\mathrm{NH}_{3}\right)_{5}{ }^{3+}$ are held together by the nitro and nitrito ligands through $\mathrm{O} \cdots \mathrm{H}-\mathrm{N}$ hydrogen bonds of 2.220 and $2.224 \AA$, respectively.

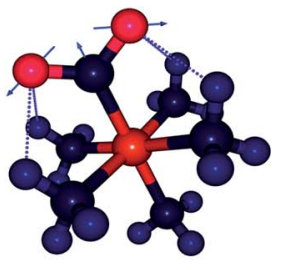

a) $820 \mathrm{~cm}^{-1}$ (deformation vibration mode)

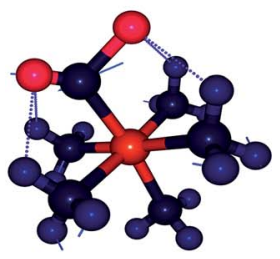

c) $1532.2 \mathrm{~cm}^{-1}$ (NO asymmetric stretching mode)

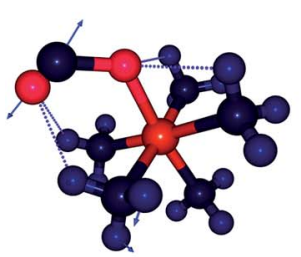

e) $1520.11 \mathrm{~cm}^{-1}$ (NO stretching mode)

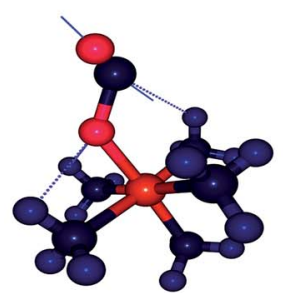

g) $1695.4 \mathrm{~cm}^{-1}$ (NO sym stretching mode)

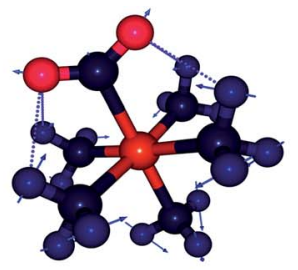

b) $1317 \mathrm{~cm}^{-1}$ (NO symmetric stretching mo de $+\mathrm{N}-\mathrm{H}$ symmetric modes)

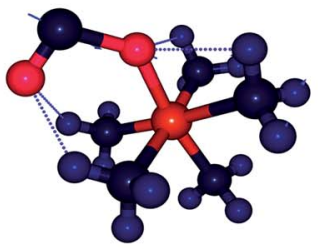

d) $968 \mathrm{~cm}^{-1}$ (NO stretching mode)

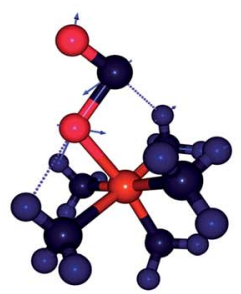

f) $888 \mathrm{~cm}^{-1}$ (deformation mode)

Fig. 5 Harmonic vibration modes of $\mathrm{NO}_{2}$ and $\mathrm{ONO}$ in $\mathrm{Co}-\mathrm{NO}_{2}(\mathrm{a}-\mathrm{c})$, endo-Co-ONO (d-e) and exo-Co-ONO (f-g) computed at B3LYP/6$31+G(d, p)$. 
Origin of mechanical motion in solids. The electronic spatial extents $^{85}$ of $\left[\mathrm{Co}\left(\mathrm{NH}_{3}\right)_{5} \mathrm{ONO}_{2}\right]^{2+}$ and $\left[\mathrm{Co}\left(\mathrm{NH}_{3}\right)_{5} \mathrm{NO}_{2}\right]^{2+}$ were computed to gauge the increase in the size of those cations upon intramolecular conversion. The exo-Co-ONO has a larger electronic spatial extent than $\mathrm{Co}-\mathrm{NO}_{2}$ : these are estimated to be about 1556 and 1411 a.u., respectively (1451 for endo-Co-ONO). The effective size of the exo-Co-ONO isomer was evaluated to be 1.2 times greater than that of the $\mathrm{NO}_{2}-{ }^{-C o}{ }^{16,17}$ According to Boldyreva, ${ }^{24}$ the former is expected to play an important role in increasing the local pressure near the product in nitro and nitrito interconversion reaction in solids, and can be at the origin of the mechanical motion observed in crystals. Thus, it is important to first understand this isomerization reaction as this constitutes the fundamental process that triggers the photosalient phenomenon in $\left[\mathrm{Co}\left(\mathrm{NH}_{3}\right)_{5} \mathrm{NO}_{2}\right] \mathrm{NO}_{3} \mathrm{Cl}$.

\subsubsection{Thermodynamic and kinetic stability}

Relative energy. Table 5 compares the relative energies of exoCo-ONO and endo-Co-ONO complexes and their transitions states (TS1 and TS2) with respect to the $\mathrm{Co}-\mathrm{NO}_{2}$ isomer at $\omega \mathrm{B} 97 \mathrm{XD} / 6-31+\mathrm{G}(\mathrm{d}, \mathrm{p})$. According to the data listed in Table 5 , the $\mathrm{Co}-\mathrm{NO}_{2}$ complex is 1.32 and $3.39 \mathrm{kcal} \mathrm{mol}^{-1}$ lower than endoCo-ONO and exo-Co-ONO complexes, respectively (1.12 and $2.00 \mathrm{kcal} \mathrm{mol}^{-1}$ at $\left.\operatorname{CCSD}(\mathrm{T}) / 6-31 \mathrm{G}(\mathrm{d})\right)$ on the potential energy surface (PES). Noted that the relative energy of the exo-Co-ONO computed by Ciofini et al..$^{33}$ is about $3.9 \mathrm{kcal} \mathrm{mol}^{-1}$ at B3LYP/ LanL2DZ including ZPE corrections in gas phase. Thus, the nitro form is predicted to be the lowest isomer. The fact that the $\omega \mathrm{B} 97 \mathrm{XD} / 6-31+\mathrm{G}(\mathrm{d}, \mathrm{p})$ energy ordering of isomers is reconfirmed by $\operatorname{CCSD}(\mathrm{T})$ (Table S5 $\dagger$ ) shows that the $\omega \mathrm{B} 97 \mathrm{XD}$ functional is an alternative method at an affordable cost for studying these linkage isomers. The dispersion energies in $\mathrm{NO}_{2}-\mathrm{Co}$, endo-Co$\mathrm{ONO}$, and exo-Co-ONO isomers computed using dispersioncorrected B3LYP at $6-31+\mathrm{G}(\mathrm{d}, \mathrm{p})$ amount to $-26.25,-25.43$ and $-24.95 \mathrm{kcal} \mathrm{mol}^{-1}$, respectively. The zero-order regular approximation (ZORA), a two-component form of the fullyrelativistic Dirac equation used along with B3LYP at SVP, also indicates that $\mathrm{Co}-\mathrm{NO}_{2}$ is the most stable isomer, followed by endo-Co-ONO. The difference in relative energies obtained using non-relativistic and relativistic method is small, ranging from 0.13 to $0.5 \mathrm{kcal} \mathrm{mol}^{-1}$.

Binding energy. The binding energies of $\mathrm{NH}_{3}$ and $\mathrm{NO}_{2}{ }^{-}$to the metal in Co-complexes and the formation energy (FE) of complexes were obtained as electronic energy $(E)$ difference between the most stable geometries of the products and

Table 5 Relative electronic energies, enthalpies, free energies (in kcal $\mathrm{mol}^{-1}$ ), entropies (in $\mathrm{cal} \mathrm{mol}^{-1}$ ) and HOMO-LUMO gap energies (in eV) of the ground states of different isomers and corresponding transition states computed at $\omega B 97 X D / 6-31+G(d, p)$

\begin{tabular}{lrrrll}
\hline gs, TS & \multicolumn{1}{c}{$\Delta E$} & \multicolumn{1}{c}{$\Delta H$} & \multicolumn{1}{c}{$\Delta G$} & \multicolumn{1}{c}{$\Delta S$} & $\mathrm{H}-\mathrm{L}$ \\
\hline Co-NO $_{2}$ & 0.00 & 0.00 & 0.00 & 0.00 & 8.68 \\
Endo-Co-ONO & 1.32 & 0.90 & 2.47 & -5.25 & 7.92 \\
Exo-Co-ONO & 3.39 & 3.58 & 3.53 & 0.17 & 7.64 \\
TS1 & 39.48 & 39.35 & 40.01 & -2.22 & - \\
TS2 & 11.00 & 10.95 & 11.00 & -0.16 & - \\
TS3 & 41.87 & 41.77 & 42.46 & -2.30 & -
\end{tabular}

reactants at $\omega \mathrm{B} 97 \mathrm{XD} / 6-31+\mathrm{G}(\mathrm{d}, \mathrm{p})$ from the following equations:

$$
\begin{gathered}
\mathrm{Co}\left(\mathrm{NH}_{3}\right)_{5}^{3+}+\mathrm{NH}_{3} \rightarrow \mathrm{Co}\left(\mathrm{NH}_{3}\right)_{6}^{3+} \\
\mathrm{Co}\left(\mathrm{NH}_{3}\right)_{5}^{3+}+\mathrm{NO}_{2}^{-} \rightarrow \mathrm{Co}\left(\mathrm{NH}_{3}\right)_{5} \mathrm{NO}_{2}^{2+} \\
\mathrm{Co}\left(\mathrm{NH}_{3}\right)_{6}^{3+}+\mathrm{NO}_{2}^{-} \rightarrow \mathrm{Co}\left(\mathrm{NH}_{3}\right)_{5} \mathrm{NO}_{2}^{2+}+\mathrm{NH}_{3} \\
\mathrm{FE}=E_{\left(\mathrm{Co}\left(\mathrm{NH}_{3}\right)_{5} \mathrm{NO}_{2}{ }^{2+}\right)}+E_{\left(\mathrm{NH}_{3}\right)}-E_{\left(\mathrm{Co}\left(\mathrm{NH}_{3}\right)_{6}^{3+}\right)}-E_{\mathrm{NO}_{2}}
\end{gathered}
$$

The heat of formation of $\mathrm{Co}\left(\mathrm{NH}_{3}\right)_{5} \mathrm{NO}_{2}{ }^{2+}$ at $298 \mathrm{~K}$ calculated by means of the isodesmic reaction (eqn (5)) is $-280.55 \mathrm{kcal} \mathrm{mol}^{-1}$. The binding energies of $\mathrm{NO}_{2}$ and $\mathrm{NH}_{3}$ to the metal Co were found to be about -343.49 and $-61.70 \mathrm{kcal} \mathrm{mol}^{-1}$, showing that $\mathrm{NO}_{2}$ binds more strongly to $\mathrm{Co}$ than $\mathrm{NH}_{3}$ does. Thus, the $\mathrm{Co}\left(\mathrm{NH}_{3}\right)_{5} \mathrm{NO}_{2}{ }^{2+}$ complex appears to be thermodynamically more stable than $\mathrm{Co}\left(\mathrm{NH}_{3}\right)_{6}{ }^{3+}$.

HOMO-LUMO \& transition states. In conceptual DFT formalism, the HOMO-LUMO gap energy is related to the kinetic stability. The $\mathrm{NO}_{2}$-Co complex in Table 4 has the largest HOMO-LUMO gap of $8.68 \mathrm{eV}$, followed by endo-Co-ONO with a HOMO-LUMO gap energy of $7.92 \mathrm{eV}$. The HOMO-LUMO of exo-Co-ONO is $0.28 \mathrm{eV}$ lower than that of endo-Co-ONO at $\omega \mathrm{B} 97 \mathrm{XD} / 6-31+\mathrm{G}(\mathrm{d}, \mathrm{p})$. Therefore, by considering the HOMOLUMO gap energy, $\mathrm{Co}-\mathrm{NO}_{2}$ appears to be kinetically more stable than ONO-Co complexes. For this purpose, two trajectories involving TS1 and TS2 transitions states were investigated by exploring the ground state potential energy surface of $\left[\mathrm{Co}\left(\mathrm{NH}_{3}\right)_{5} \mathrm{NO}_{2}\right]^{2+}$ : the trajectory from the Co- $\mathrm{NO}_{2}$ to endo-CoONO complex and that from the endo-Co-ONO to exo-Co-ONO complex. The mechanistic study of the intramolecular conversion reveals that the energy barrier for the intramolecular conversion of endo-Co-ONO in $\mathrm{Co}-\mathrm{NO}_{2}\left(\sim 39 \mathrm{kcal} \mathrm{mol}^{-1}\right)$ is 3.5 times larger than that of the interconversion between endo-CoONO and exo-Co-ONO. Our TS1 activation energy barrier carried out at $\omega \mathrm{B} 97 \mathrm{XD} / 6-31+\mathrm{G}(\mathrm{d}, \mathrm{p})$ is $9 \mathrm{kcal} \mathrm{mol}^{-1}$ above the activation energies computed at B3LYP/LanL2DZ (5 kcal mol ${ }^{-1}$ at B3LYP/ LanL2DZp) by Ciofini et al. ${ }^{33}$

Relative free energies. The relative free energies, enthalpies and entropies of the ground and transition states of the $\mathrm{Co}\left(\mathrm{NH}_{3}\right)_{5} \mathrm{NO}_{2}{ }^{2+}$ isomers calculated at the $\omega \mathrm{B} 97 \mathrm{XD} / 6-31+\mathrm{G}(\mathrm{d}, \mathrm{p})$ theory level provided in Table 5 suggest that a direct transformation from nitro to exo-Co-ONO required more energy than that required for the transformation via the intermediate endoCo-ONO. The energy difference between the activated complexes TS1 and TS3 is about $2.39 \mathrm{kcal} \mathrm{mol}^{-1}$. endo-Co-ONO appears to be more structured (low relative entropy) than $\mathrm{Co}^{-}$ $\mathrm{NO}_{2}$ and exo-Co-ONO. The entropic energy differences can be associated with the strength of the hydrogen bonding in these systems. Overall, the entropy differences in these complexes are quite small ranging from 0.2 to $5 \mathrm{cal} \mathrm{mol}^{-1}$ and do not significantly affect the relative stabilities of $\mathrm{Co}-\mathrm{NO}_{2}$ and $\mathrm{Co}-\mathrm{ONO}$ complexes and their transition states. Because of the large energy of the TS2 transition-state, the molecular conversion between nitro and endo-nitrito is predicted to be the slow step of the reaction and may determine the rate of the intramolecular 


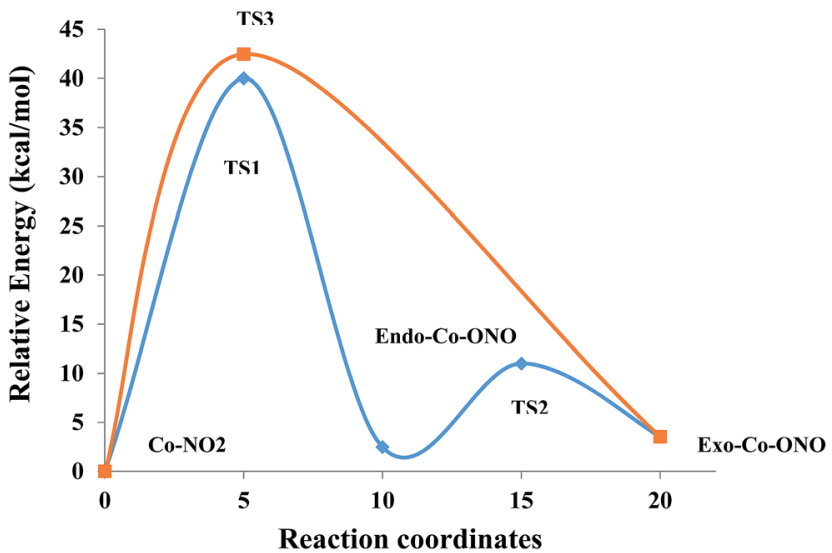

Fig. 6 Reaction pathway of the conversion of the $\mathrm{Co}-\mathrm{NO}_{2}$ into exoCo-ONO at $\omega B 97 X D / 6-31+G(d, p)$ in gase phase.

conversion between the $\mathrm{Co}-\mathrm{NO}_{2}$ and exo-Co-ONO complexes. The most likely reaction mechanism involves starting from $\mathrm{Co}-$ $\mathrm{NO}_{2}$ and then transforming into the endo-Co-ONO intermediate and finally into exo-Co-ONO:

$$
\begin{array}{r}
\mathrm{Co}\left(\mathrm{NH}_{3}\right)_{5} \mathrm{NO}_{2}{ }^{2+} \rightarrow\left[\mathrm{Co}\left(\mathrm{NH}_{3}\right)_{5} \mathrm{NO}_{2}{ }^{2+}\right]^{\neq}(\mathbf{T S 1}) \rightarrow \\
\text { endo- } \mathrm{Co}\left(\mathrm{NH}_{3}\right)_{5} \mathrm{ONO}^{2+}
\end{array}
$$

$$
\begin{array}{r}
\text { endo- } \mathrm{Co}\left(\mathrm{NH}_{3}\right)_{5} \mathrm{ONO}^{2+} \rightarrow\left[\mathrm{Co}\left(\mathrm{NH}_{3}\right)_{5} \mathrm{NO}_{2}^{2+}\right]^{\neq}(\mathbf{T S 2}) \rightarrow \\
\text { exo- } \mathrm{Co}\left(\mathrm{NH}_{3}\right)_{5} \mathrm{ONO}^{2+}
\end{array}
$$

The pathway (1) proceeds through the higher-energy transition state (TS1), but yields the lower-energy nitrito conformer (endo-Co-ONO) (Fig. 6 and S5†). The second pathway (2) leads through the lower-energy transition (TS2), but yields a relatively higher-energy nitrito conformer (exo-Co-ONO). Therefore, the pathways (1) and (2) of the interconversion of $\mathrm{Co}-\mathrm{NO}_{2}$ in exo-CoONO can be assumed to be respectively, the thermodynamically-favored and the kinetically-favored pathways (Fig. 6). TS4 and chelate structure (Fig. 1e) were also proposed as possible transition states. ${ }^{11}$ Our calculations show that the former (TS4, i95 $\mathrm{cm}^{-1}$ ) requires $\sim 233 \mathrm{kcal} \mathrm{mol}^{-1}$, while the chelate structure possesses several imaginary frequencies and relaxes towards TS2. However, the possibility of the reaction occurring via the TS4 state at standard conditions in gas phase is very low as the activation energy is too high. The reorientation of the $\mathrm{NO}_{2}$ ligand slightly changes the magnitude of the dipole moments from $10 \mathrm{D}$ in $\mathrm{Co}-\mathrm{NO}_{2}$ to $11 \mathrm{D}$ in exo-Co-ONO $10 \mathrm{D}$ in endo-Co-ONO). With regards to the relative stabilities of linkage isomers, our results agree with previously reported experimental results, ${ }^{17,18}$ and these can justify the reorientation of the $\mathrm{NO}_{2}$ moiety in the $\left[\mathrm{Co}\left(\mathrm{NH}_{3}\right)_{5} \mathrm{NO}_{2}\right] \mathrm{ClNO}_{3}$ isomer upon UV irradiation to form the exo-[Co( $\left.\left(\mathrm{NH}_{3}\right)_{5} \mathrm{ONO}\right] \mathrm{ClNO}_{3}$ isomer and the slow conversion of the less stable exo- $\left[\mathrm{Co}\left(\mathrm{NH}_{3}\right)_{5} \mathrm{ONO}\right] \mathrm{ClNO}_{3}$ complex into $\left[\mathrm{Co}\left(\mathrm{NH}_{3}\right)_{5} \mathrm{NO}_{2}\right] \mathrm{ClNO}_{3}$ in the dark. The fast conversion of endo-Co-ONO in the exo-Co-ONO conformer explains why the former has never been observed experimentally.

3.2.3 Chemical bonding analysis. In this section, we focus our analysis on the hydrogen bonding properties of the nitro and nitrito groups in $\mathrm{Co}-\mathrm{NO}_{2}$ and $\mathrm{Co}-\mathrm{ONO}$ complexes, respectively, in an attempt to support their rank order of stabilities. Fig. 7 depicts the molecular graphs obtained from atoms in molecules (AIM) ${ }^{86}$ analysis of Co- $\mathrm{NO}_{2}$ and Co-ONO complexes. The molecular graphs of these complexes have bond critical points (bcps) between $\mathrm{H}$ and ONO that clearly show that nitro and nitrito are interconnected with ammonia through $\mathrm{O} \cdots \mathrm{H}-\mathrm{N}$ and $\mathrm{N} \cdots \mathrm{H}-\mathrm{N}$ intramolecular hydrogen bonds (IHBs), respectively. The electron densities and their Laplacians at different bcps in the three Co-complexes are given in Table 6. The negative values of the Laplacians along $\mathrm{N} \cdots \mathrm{H}-\mathrm{N}$, and $\mathrm{O} \cdots \mathrm{H}-\mathrm{N}$ bonds indirectly indicate that electrons are concentrated in these inter-nuclear regions. The O21 $\cdots \mathrm{H} 12-\mathrm{N} 19$ and $\mathrm{O} 21 \cdots \mathrm{N} 19$ bond lengths in endo-Co-ONO are 2.01 and $2.86 \AA$, respectively, leading to the possibility of competing $\mathrm{O} \cdots \mathrm{N}$ and $\mathrm{O} \cdots \mathrm{H}$ intramolecular interactions. The $\mathrm{O} 21 \cdots \mathrm{N} 19$ bond length in endo-CoONO lies in the same range as the $\mathrm{N} \cdots \mathrm{O}$ bond length (less than 3 A) observed in crystals where nitro groups were arranged perpendicular to each other. ${ }^{87}$ The $\mathrm{N} \cdots \mathrm{O}$ bond is weaker than $\mathrm{N} \cdots \mathrm{H}$ and $\mathrm{O} \cdots \mathrm{H}$ bonds owing to the repulsion between lone pairs. ${ }^{88}$ The total NBO charge transfer energies ${ }^{\mathbf{8 9}, 90}$ from lone pairs (LPs) of $\mathrm{N}$ and $\mathrm{O}$ of $\mathrm{ONO}$ atoms group to the $\mathrm{N}-\mathrm{H} \sigma^{*}$ antibonding orbitals are estimated to be about 10.49, 15.19, and

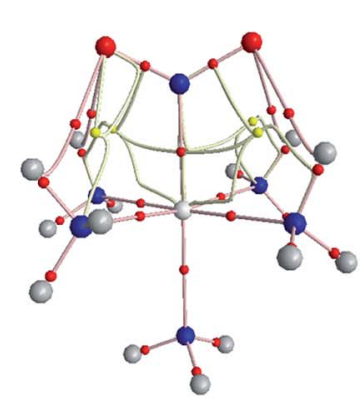

(a)

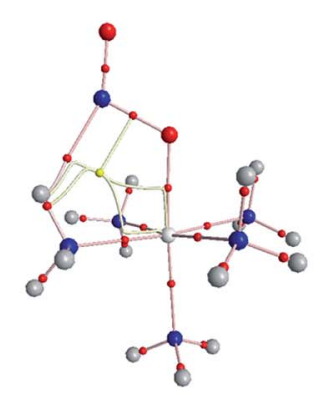

(b)

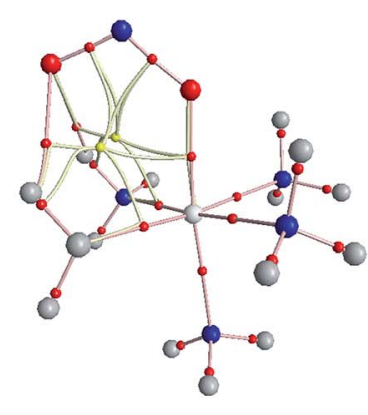

(c)

Fig. 7 Molecular graphs (set of bond paths and critical points) of (a) $\mathrm{Co}-\mathrm{NO}_{2}$ and $(\mathrm{b}-\mathrm{c}) \mathrm{Co}-\mathrm{ONO}$ complexes obtained from AIM analysis of $\omega \mathrm{B} 97 \mathrm{XD} / 6-31+\mathrm{G}(\mathrm{d}, \mathrm{p})$ wave function. Color code: large spheres (red: O, blue: N, grey: H, white: Co) and small spheres (red: bond critical points, and yellow: ring critical point). 
Table $6 \mathrm{~N} \cdots \mathrm{H}-\mathrm{N}$ and $\mathrm{O} \cdots \mathrm{H}-\mathrm{N}$ NBO second-order perturbation energies $E(2)$ (in $\mathrm{kcal} \mathrm{mol}^{-1}$ ) and electron density ( $\rho$ ) at the bcp and its Laplacian $\left(\nabla^{2} \rho\right)$ in parenthesis computed at $\omega B 97 X D / 6-31+G(d, p)$

\begin{tabular}{|c|c|c|c|}
\hline Isomers & H Charge transfer & NBO E(2) & $\rho\left(\nabla^{2} \rho\right)$ \\
\hline & $\begin{array}{l}\mathrm{O} 12(\mathrm{LP}) \rightarrow \mathrm{N} 7-\mathrm{H} 22\left(\sigma^{*}\right) \\
\mathrm{O} 12(\mathrm{LP}) \rightarrow \mathrm{N} 5-\mathrm{H} 16\left(\sigma^{*}\right) \\
\mathrm{O} 11(\mathrm{LP}) \rightarrow \mathrm{N} 2-\mathrm{H} 8\left(\sigma^{*}\right) \\
\mathrm{O} 11(\mathrm{LP}) \rightarrow \mathrm{N} 4-\mathrm{H} 15\left(\sigma^{*}\right) \\
\text { Total } E(2)\end{array}$ & $\begin{array}{r}5.66 \\
3.92 \\
2.51 \\
3.10 \\
15.19\end{array}$ & $\begin{array}{l}0.020(-0.018) \\
0.017(-0.016) \\
0.016(-0.016) \\
0.019(-0.018)\end{array}$ \\
\hline & $\begin{array}{l}\mathrm{O} 21(\mathrm{LP}) \rightarrow \mathrm{N} 19-\mathrm{H} 12\left(\sigma^{*}\right) \\
\mathrm{O} 21(\mathrm{LP}) \rightarrow \mathrm{N} 7-\mathrm{H} 20\left(\sigma^{*}\right) \\
\mathrm{O} 24(\mathrm{LP}) \rightarrow \mathrm{N} 16-\mathrm{H} 4\left(\sigma^{*}\right) \\
\text { O24(LP) } \rightarrow \mathrm{N} 17-\mathrm{H} 14\left(\sigma^{*}\right) \\
\text { Total } E(2)\end{array}$ & $\begin{array}{r}7.96 \\
7.06 \\
0.99 \\
1.23 \\
17.24\end{array}$ & $\begin{array}{l}0.024(-0.018) \\
0.022(-0.018) \\
-\end{array}$ \\
\hline & $\begin{array}{l}\mathrm{N} 22(\mathrm{LP}) \rightarrow \mathrm{N} 6-\mathrm{H} 10\left(\sigma^{*}\right) \\
\mathrm{O} 23(\mathrm{LP}) \rightarrow \mathrm{N} 5-\mathrm{H} 7\left(\sigma^{*}\right) \\
\mathrm{O} 23(\mathrm{LP}) \rightarrow \mathrm{N} 3-\mathrm{H} 13\left(\sigma^{*}\right) \\
\text { Total } E(2)\end{array}$ & $\begin{array}{r}7.74 \\
1.24 \\
1.51 \\
10.49\end{array}$ & $\begin{array}{l}0.022(-0.018) \\
-\end{array}$ \\
\hline
\end{tabular}

$17.24 \mathrm{kcal} \mathrm{mol}^{-1}$ in exo-Co-ONO, $\mathrm{Co}-\mathrm{NO}_{2}$, and endo-Co-ONO, respectively (Table 6); this indicates that intramolecular hydrogen bond strength increases in the following order: exonitrito < nitro < endo-nitro. The Co-O bond (NBO energy $\sim$ $-1.00 \mathrm{kcal} \mathrm{mol}^{-1}$ ) is slightly more stable than the Co-N bond (NBO energy of $-0.97 \mathrm{kcal} \mathrm{mol}^{-1}$ ). The stabilization energy $E(2)$ associated with electron delocalization arising from the donor LPs of Co (d orbitals) to the acceptor $\mathrm{Pi}^{*}$ of $\mathrm{NO}_{2}$ is estimated about $7.01 \mathrm{kcal} \mathrm{mol}^{-1}$ while that arising from Co to $\mathrm{Pi}^{*} \mathrm{ONO}$ amount to be about $1 \mathrm{kcal} \mathrm{mol}^{-1}\left(0.93 \mathrm{kcal} \mathrm{mol}^{-1}\right.$ in exo-CoONO and 0.68 in endo-Co-ONO) computed at B3LYP/6-31G(d). This result shows that $\mathrm{NO}_{2}$ is a good pi* acceptor than ONO and is more favorable to pi*-back-bonding than the nitrito. Hence, the nitrito appears as a weaker pi electron acceptor than nitro. The latter can also explain the extra-stability of $\mathrm{Co}-\mathrm{NO}_{2}$ complex compare to Co-ONO complexes.

The difference in the electronic structure between $\mathrm{Co}-\mathrm{NO}_{2}$, endo-Co-ONO and exo-Co-ONO is shown in Table S6. $\dagger$ The $\mathrm{N}-\mathrm{O}$ Mayer bond order and electrons occupancies of $\mathrm{Co}-\mathrm{NO}_{2}$ and Co-ONO complexes are given in Table 7. The two $\mathrm{N}-\mathrm{O}$ bonds in nitro have a 1.50 Mayer bond order, whereas in endo-Co-ONO, they are about 1.16 and 1.67 and are nearly 1.91 and 0.98 in exoCo-ONO. These computed bond orders show that the electron density charge is delocalized over the two $\mathrm{N}-\mathrm{O}$ bonds in $\mathrm{Co}-\mathrm{NO}_{2}$ giving both of them a partial double bond character, while the electron delocalization is diminishing in Co-ONO. The electronic density delocalization over $\mathrm{N}-\mathrm{O}$ bonds diminishes the most when nitro is converted in exo-Co-ONO. These findings suggest that the electron resonance in these complexes assists intramolecular hydrogen bonds and can justify the ranking relative stabilities of isomers. The electrostatic attraction between the Co and $\mathrm{O}$ atoms was proposed as driving force of the linkage isomerization due to the fact that the $\mathrm{O}$ atoms are rich in electrons than $\mathrm{N}$ in $\mathrm{NO}_{2}$ ligand. ${ }^{91,92}$ Fig. 8 shows the ELF

Table 7 Mayer bond order of some selected bonds of nitro and nitrito-complexes computed at B3LYP/SVP (NBO occupancies at $B 3 L Y P / 6-31 G(d))$

\begin{tabular}{llll}
\hline Bonds & Endo & Exo & Nitro \\
\hline $\mathrm{H}-\mathrm{N}$ & $0.95(1.99)$ & $0.95(1.99)$ & $0.96(1.99)$ \\
$\mathrm{H}_{3} \mathrm{~N}-\mathrm{Co}$ & $0.66(1.97)$ & $0.66(1.97)$ & $0.67(1.97)$ \\
$\mathrm{Co}-\mathrm{O}$ & $0.68(1.93)$ & $0.83(1.92)$ & - \\
$\mathrm{N}-\mathrm{Co}$ & - & - & $0.51(1.93)$ \\
$\mathrm{O}-\mathrm{N}$ & $1.67(1.99,1.99)$ & $1.91(2.00,1.99)$ & $1.50(1.99,1.99)$ \\
$\mathrm{N}-\mathrm{O}^{a}$ & $1.16(1.98)$ & $0.98(1.99)$ & $1.50(1.99)$ \\
$\mathrm{LP}(\mathrm{O})$ & $(1.97,1.85)$ & $(1.99,1.82)$ & $(1.97,1.84,1.44)$ \\
$\mathrm{LP}(\mathrm{O})^{a}$ & $(1.92,1.70)$ & $(1.93,1.77)$ & $(1.97,1.84)$ \\
$\mathrm{LP}(\mathrm{N})^{b}$ & $(1.91)$ & $(1.91)$ & - \\
$\mathrm{LP}(\mathrm{Co})$ & $(1.98,1.97,1.97)$ & $(1.97,1.97,1.97)$ & $(1.98,1.94,1.97)$
\end{tabular}

${ }^{a} \mathrm{O}$ bound to Co in endo and exo-nitrito complexes. ${ }^{b}$ LPs of $\mathrm{N}$ of nitro or nitrito. 

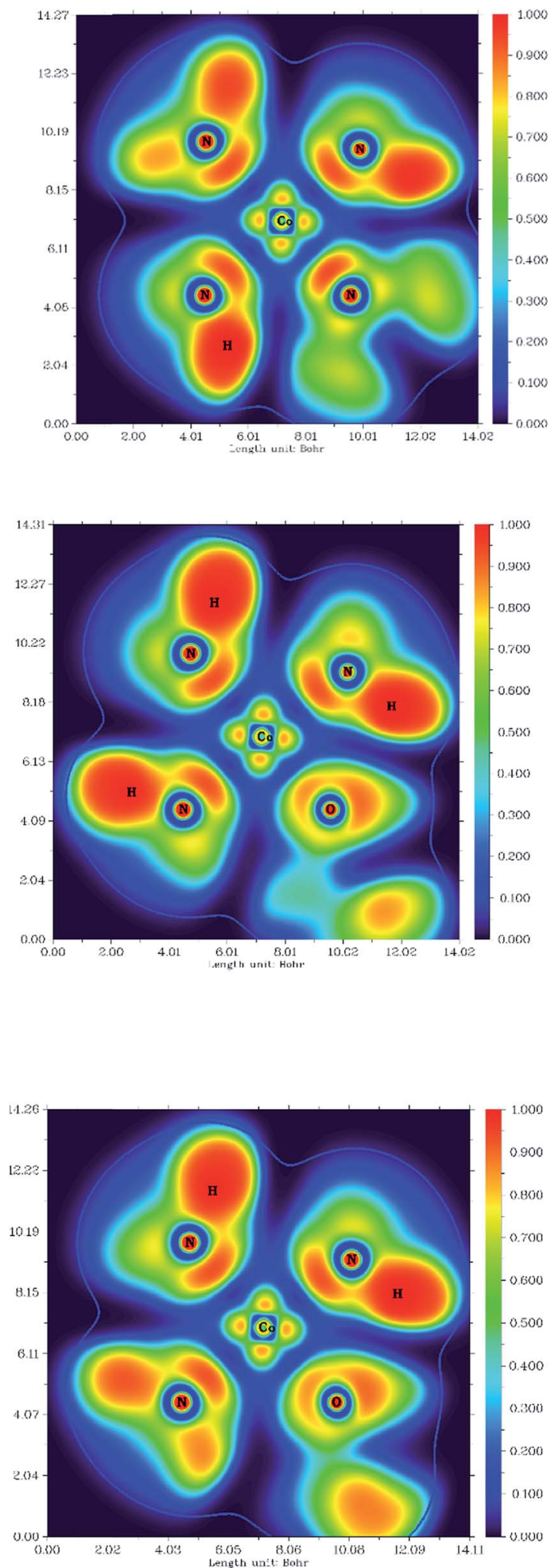
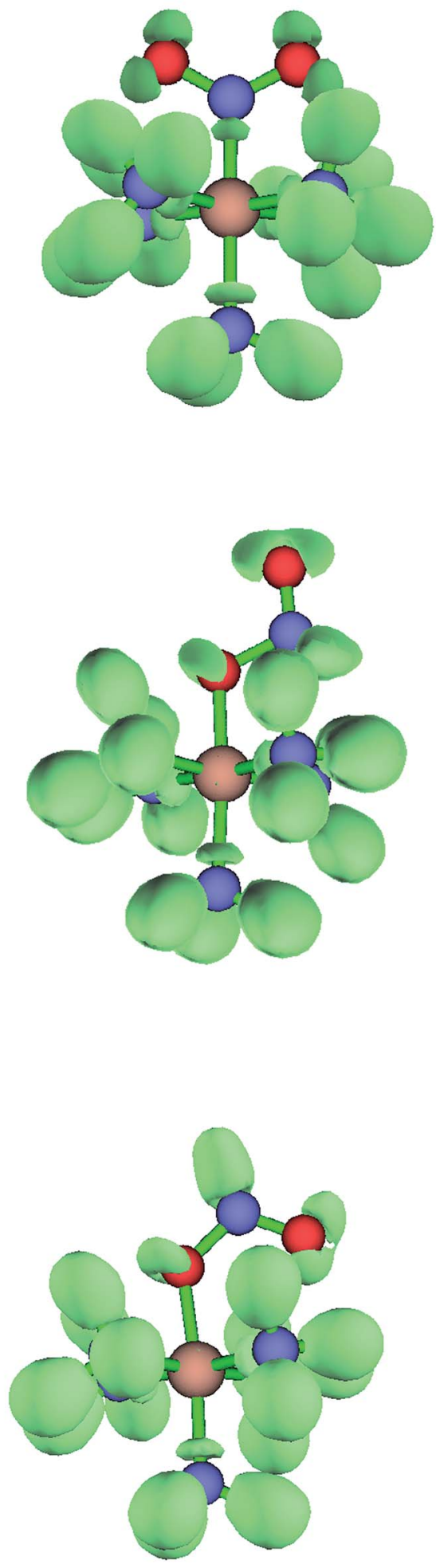

Fig. 8 Electron localized function (ELF) in 2D (left) and 3D (right) of endo-Co-ONO.

isosurfaces of nitro and nitrito complexes and their cut planes. The topologies of the molecular electron densities are similar, but a small difference can be noticed around $\mathrm{ONO}$ and $\mathrm{NO}_{2}$ (Table S7 $\dagger$ ). The $\mathrm{N}-\mathrm{H}$ bond is of polar covalent type, while the bonds formed between Co and $\mathrm{NH}_{3}$ are of dative type, as indicated by the orientation of the lone pairs of electrons located on N. The ELF and electron density Laplacian cut planes (Fig. 8 and 9) clearly indicate the lone pair region of nitrogen 


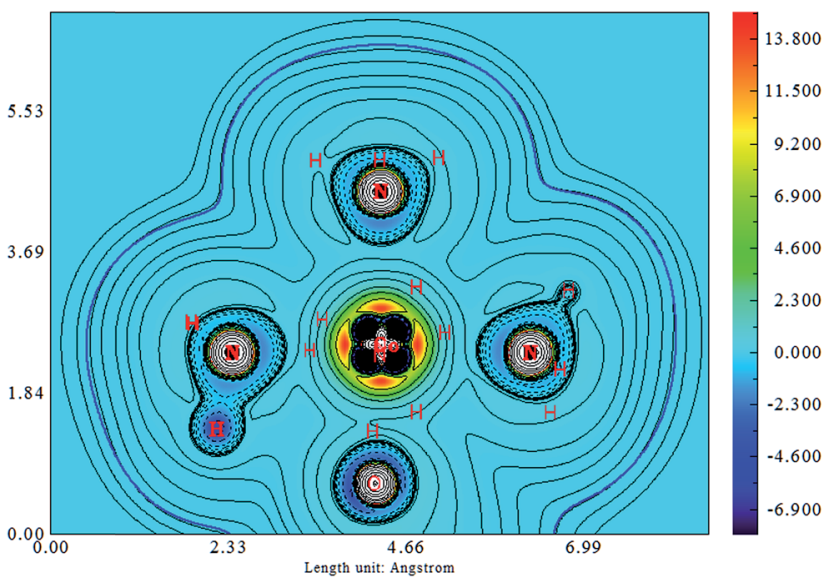

Fig. 9 Laplacian in endo-Co-ONO

and electron deficiency in Co that enable the $\mathrm{NH}_{3}$ donor ligand to form a dative bond.

\section{Conclusion}

The nitro-nitrito isomerization in $\mathrm{Co}\left(\mathrm{NH}_{3}\right)_{5} \mathrm{NO}_{2}{ }^{2+}$ linkage isomers was investigated from a theoretical perspective using quantum chemical calculations at $\omega \mathrm{B} 97 \mathrm{XD} / 6-31+\mathrm{G}(\mathrm{d}, \mathrm{p})$, emphasizing on the structural, thermodynamic, and chemical bonding properties of the isomers. This isomerization is fundamental for a better understanding of the photo-salient effect in $\left[\left(\mathrm{NH}_{3}\right)_{5} \mathrm{CoNO}_{2}\right] \mathrm{ClNO}_{3}$. The Bader theory based on the partitioning of electron density, the electron localization function, and natural bond orbitals were used for chemical bonding analysis. Our computational study led to the following conclusions:

(a) The nitrito/exo-nitrito isomerization reaction is predicted to occur via the following reaction pathway:

$$
\begin{array}{r}
\mathrm{Co}\left(\mathrm{NH}_{3}\right)_{5} \mathrm{NO}_{2}{ }^{2+} \rightarrow\left[\mathrm{Co}\left(\mathrm{NH}_{3}\right)_{5} \mathrm{NO}_{2}{ }^{2+}\right]^{\neq}(\mathrm{TS1}) \rightarrow \\
\text { endo- } \mathrm{Co}\left(\mathrm{NH}_{3}\right)_{5} \mathrm{ONO}^{2+}
\end{array}
$$

(b) The intramolecular conversion on the ground-state potential energy surface of $\mathrm{Co}-\mathrm{NO}_{2}$ between endo-Co-ONO and exo-Co-ONO complexes is kinetically controlled and that leading to the $\mathrm{Co}-\mathrm{NO}_{2}$ complex formation is thermodynamically controlled.

(c) $\mathrm{O} \cdots \mathrm{H}-\mathrm{N}$ and $\mathrm{N} \cdots \mathrm{H}-\mathrm{N}$ intramolecular hydrogen bonds, orientation of the atoms of the ONO group, and the difference in $\mathrm{Co}-\mathrm{N}$ and $\mathrm{Co}-\mathrm{O}$ bond energies are identified as key factors determining the relative stabilities of the $\mathrm{Co}-\mathrm{NO}_{2}$ and $\mathrm{Co}-\mathrm{ONO}$ linkage isomers.

(d) $\mathrm{Co}\left(\mathrm{NH}_{3}\right)_{6}{ }^{3+}$ is less stable compared to $\mathrm{Co}\left(\mathrm{NH}_{3}\right)_{5} \mathrm{NO}_{2}{ }^{2+}$ and undergoes a slight geometry distortion from $D_{3 \mathrm{~d}}$ to $D_{3}$ characterized by a PJTE of $741 \mathrm{~cm}^{-1}$ at $\omega \mathrm{B} 97 \mathrm{XD} / 6-31+\mathrm{G}(\mathrm{d}, \mathrm{p})\left(750 \mathrm{~cm}^{-1}\right.$ at $\operatorname{CCSD}(T) / 6-31+G(d, p))$. It is worth noting that the hydrogen can freely rotate to keep the high octahedral symmetry.

The photo-isomerization of the $\left[\mathrm{Co}\left(\mathrm{NH}_{3}\right)_{5} \mathrm{NO}_{2}\right]^{2+}$ complex is currently under investigation in our lab to determine the role of conical intersection and excited states in the UV-initiated intramolecular conversion of $\left[\mathrm{Co}\left(\mathrm{NH}_{3}\right)_{5} \mathrm{NO}_{2}\right] \mathrm{NO}_{3} \mathrm{Cl}$.

\section{Conflicts of interest}

The authors declare that they have no conflict of interest.

\section{Acknowledgements}

This research was supported by Korea Research Fellowship program and grants from the Basic Science Research Program funded by the Ministry of Science, ICT and Future Planning through the National Research Foundation of Korea (NRF2015H1D3A1062502, NRF-2015R1C1A1A02036670, NRF2015R1A2A2A01006445). JTM thanks Prof. Carol Parish for the support and permissions to use the facilities and computing resources of the University of Richmond and Dr Harry Ramanantoanina from the Paul Scherrer Institute in Switzerland for helpful discussion.

\section{References}

1 K. Czarnek, S. Terpiłowska and A. K. Siwicki, Cent. Eur. J. Immunol., 2015, 40, 236.

2 A. Werner, Über strukturisomere Salze der Rhodanwasserstoffsäure und der salpetrigen Säure, Ber. Dtsch. Chem. Ges., 1907, 40, 765.

$3 \mathrm{H}$. Hiroshi Sakiyama, Y. Ishiyama and H. Sugawara, Spectrosc. Lett., 2017, 50, 111.

4 N. N. Greenwood, Spectroscopic properties of inorganic and organometallic compounds, Burlington House, London, 1970, vol. 3, p. 501.

5 R. P. Sharma, R. Bala, R. Sharma and V. Ferreti, Inorg. Chim. Acta, 2005, 358, 3457.

6 R. P. Sharma, R. Bala, R. Sharma, K. K. Bhasin and R. K. Chadha, J. Coord. Chem., 2004, 57, 313.

7 S. Rudisser and I. Tinoco Jr, J. Mol. Biol., 2000, 295, 1211.

8 http://www.nobelprize.org/nobel_prizes/chemistry/ laureates/1913/.

9 D. A. Buckingham, I. I. Creaser and A. M. Sargeson, Inorg. Chem., 1970, 9, 655.

10 A. A. Tishkov, U. Schmidhammer, S. Roth, E. Riedle and H. Mayr, Angew. Chem., Int. Ed., 2005, 44, 4623.

11 F. Basolo and G. S. Hammaker, Inorg. Chem., 1962, 1, 1.

12 C. Buda, A. B. Kazi, A. Dinescu and T. R. Cundari, J. Chem. Inf. Model., 2005, 45, 965.

13 A. M. Heyns and D. de Waal, Spectrochim. Acta, Part A, 1989, 45, 905.

14 O. Bortin, Acta Chem. Scand., 1968, 22, 2890.

15 M. Kubota and S. Ohba, Acta Crystallogr., 1992, B48, 627.

16 H. Hohman, J. Chem. Educ., 1974, 51, 553.

17 R. G. Pearson, P. M. Henry, J. G. Bergmann and F. Basolo, J. Am. Chem. Soc., 1954, 76, 5920.

18 I. Grenthe and E. Nordin, Inorg. Chem., 1979, 18, 1869.

19 V. Balzani, R. Ballardi, N. Sabbatin and L. Moggi, Inorg. Chem., 1968, 7, 1398. 
20 D. A. Johnson and K. A. Pashman, Inorg. Nucl. Chem. Lett., 1975, 11, 23.

21 B. A. Zakharov, A. S. Marchuk and E. V. Boldyreva, CrystEngComm, 2015, 17, 8812.

22 P. Naumov, S. Chandra Sahoo, B. A. Zakharov and E. V. Boldyreva, Dynamic Single Crystals: Kinematic Analysis of Photoinduced Crystal Jumping (The Photosalient Effect), Angew. Chem., Int. Ed., 2013, 52, 9990.

23 S. S. Chandra, M. K. Panda, N. K. Nath and P. Naumov, J. Am. Chem. Soc., 2013, 135, 12241.

24 E. V. Boldyreva, A. A. Sidelnikov and N. Z. Lyakhov, Thermochim. Acta, 1985, 92, 109.

25 E. V. Boldyreva, Izv.Sib.Otd.Akad. Nauk USSR, Ser. chim. nauk, 1982, ch. 5, pp. 18-27.

26 M. Mares, D. A. Palmer and H. Kelm, Inorg. Chim. Acta, 1978, 27, 153.

27 W. G. Jackson, G. A. Lawrance, P. A. Lay and A. M. Sagerson, J. Chem. Educ., 1981, 58, 734.

28 V. Balzani, R. Ballardini, N. Sabbatini and L. Moggi, Inorg. Chem., 1968, 7, 1398.

29 W. H. Hohman, J. Chem. Educ., 1974, 51, 553.

30 D. Shriver, M. Weller, T. Overton, J. Rourke and F. Armstrong, Inorganic chemistry, Kindle Edition, 6th edn, 1995, p. 218.

31 G. Miessler, P. J. Fischer and D. A. Tarr, Inorganic Chemistry, Pearson, 5th edn, 2012, p. 333.

32 G. B. Kauffman, Coord. Chem. Rev., 1973, 11, 161.

33 (a) I. Ciofini and C. Adamo, J. Phys. Chem. A, 2001, 105, 1086; (b) R. B. Penland, T. J. Lane and J. V. Quagliano, J. Am. Chem. Soc., 1956, 78, 887.

34 M. Behl and A. Lendlein, Soft Matter, 2007, 3, 58.

35 (a) R. Medishetty, A. Husain, Z. Bai, T. Runčevski, R. E. Dinnebier, P. Naumov and J. J. Vittal, Angew. Chem., Int. Ed., 2014, 53, 5907; (b) http://io9.gizmodo.com/howinternal-explosions-make-these-crystals-leap-around1690643855.

36 J. M. Cole, Chem. Soc. Rev., 2004, 33, 501.

37 M. R. Warren, Photocrystallographic studies into linkage isomerism, PhD thesis, Chemistry, University of Bath, UK, 2011.

38 F. A. Cotton and G. Wilkinson, Advanced Inorganic Chemistry, Wiley, New York, 5th edn, 1988, p. 731.

39 J. Kozhukh, M. A. Minier and S. J. Lippard, Inorg. Chem., 2015, 54, 418.

40 N. N. Greenwood and A. Earnshaw, Chemistry of the Elements, Pergamon Press Ltd, Oxford, England, 1984.

41 G. C. Bond, Phtinzm Mutak Rw., 2000, 44, $14 \mathrm{C} 155$.

42 J. Austchbach, J. Chem. Phys., 2012, 136, 150902.

43 J. T. Muya, A. Ceulemans, G. Gopakumar and C. Parish, J. Phys. Chem. A, 2015, 119, 2015.

44 B. Richard, Atoms in Molecules: A Quantum Theory, Oxford Univ. Press, USA, 1994.

45 A. D. Becke and K. E. Edgecombe, J. Chem. Phys., 1990, 92, 5397.

46 A. Savin, O. Jepsen, J. Flad, O. K. Andersen, H. Preuss and H. G. von Schnering, Angew. Chem., Int. Ed. Engl., 1992, 31, 187.
47 F. Weinhold and C. R. Landis, Discovering Chemistry with Natural Bond Orbitals, John Wiley \& Sons, New Jersey, Hoboken, 2012, p. 319.

48 E. D. Glendening, C. R. Landis and F. Weinhold, J. Comput. Chem., 2013, 34, 1429.

49 M. J. Frisch, G. W. Trucks and H. B. Schlegel, et al., Gaussian 09, Revision D.01, Gaussian, Inc., Wallingford CT, 2009.

50 F. Neese, The ORCA program system, Wiley Interdiscip. Rev.: Comput. Mol. Sci., 2012, 2, 73.

51 F. Furche, R. Ahlrichs, C. Hättig, W. Klopper, M. Sierka and F. Weigend, Wiley Interdiscip. Rev.: Comput. Mol. Sci., 2014, 4, 91.

52 ADF, SCM, Theoretical Chemistry, Vrije Universiteit, Amsterdam, The Netherlands, 2017, http://www.scm.com.

53 R. Dennington, T. Keith and J. Millam, GaussView, Version 5 , Semichem Inc., Shawnee Mission, KS, 2009.

54 http://www.chemcraftprog.com.

55 Jmol: an open-source Java viewer for chemical structures in 3D, http://www.jmol.org/.

56 (a) F. Biegler-Konig, J. Schonbohm and D. Bayles, AIM2000 program A program to Analyze and visualize atoms in molecules, J. Comput. Chem., 2001, 22, 545; (b) AIM2000 homepage and software from, http://gauss.fh-bielefeld.de/ aim 2000 .

57 T. Lu and F. Chen, Multiwfn: A Multifunctional wavefunction analyzer, J. Comput. Chem., 2012, 33, 580.

58 D. W. Meek and J. A. Ibers, Inorg. Chem., 1970, 9, 465.

59 M. D. Newton, J. Phys. Chem., 1991, 95, 30.

60 B. S. Brunschwig, C. Creutz, D. H. Macartney, T.-K. Sham and N. Sutin, Faraday Discuss. Chem. Soc., 1982, 74, 113.

61 F. P. Rotzinger, J. Chem. Theory Comput., 2009, 5, 1061.

62 J. T. Muya, T. Sato, M. T. Nguyen and A. Ceulemans, Chem. Phys. Lett., 2012, 543, 111.

63 A. Ceulemans, Group Theory Applied to Chemistry, Springer, 2013.

64 D. B. Krisloff, V. B. Oyeyemi, F. Libisch and E. A. Carter, J. Chem. Phys., 2014, 140, 024102.

65 A. Goursot and E. Penigault, Chem. Phys., 1979, 38, 11-19.

66 B. S. Brunschwig, C. Creutz, D. H. Macartney, T.-K. Sham and N. Sutin, Faraday Discuss. Chem. Soc., 1982, 74, 113.

67 K. Saito, Y. Eishiro, Y. Nakao, H. Sato and S. Sakaki, Inorg. Chem., 2012, 51, 2785.

68 H. C. Stynes and J. A. Ibers, Inorg. Chem., 1971, 10, 2304.

69 B. F. G. Johnson, Inorganic Chemistry of the transition elements, 1972, vol. 2, p. 517.

70 K. Pierloot and S. Vancoillie, J. Chem. Phys., 2006, 125, 124303.

71 D. A. Fletcher, R. F. McMeeking and D. Parking, J. Chem. Inf. Comput. Sci., 1996, 36, 746.

72 M. Swart, J. Chem. Theory Comput., 2008, 4, 2057.

73 P. Castillo-Villalon, J. Ramırez, M.-J. Peltre, C. Louis and P. Massiani, J. Phys. Chem. B, 2003, 107, 8547.

74 C. Daul and A. Goursot, Inorg. Chem., 1985, 24, 3554.

75 O. Laporte and W. F. Meggers, J. Opt. Soc. Am., 1925, 11, 459.

76 M. J. Bearpark, L. Blancafort and M. A. Robb, Mol. Phys., 2002, 100, 1735.

77 D. J. Gross, Proc. Natl. Acad. Sci. U. S. A., 1996, 93, 14256. 
78 F. A. Cotton and W. T. Edwards, Acta Crystallogr., Sect. B: Struct. Crystallogr. Cryst. Chem., 1968, 24, 474.

79 I. Grenthe and E. Nordin, Inorg. Chem., 1979, 18, 1869.

80 E. V. Boldyreva, J. Kivikoski and J. A. K. Howard, Acta Crystallogr., 1997, C53, 526.

81 P. Gilli, V. Bertolasi, V. Ferretti and G. Gilli, J. Am. Chem. Soc., 2000, 122, 10405.

82 S. Balt, M. W. G. De Bolster, C. J. van Garderen, A. M. van Herk, K. R. Lammers and E. G. van der Velde, Inorg. Chim. Acta, 1985, 106, 43.

83 W. L. Jolly, The Synthesis and Characterization of Inorganic Compounds, 1970.

84 H. Leonhardt and A. Weller, Phys. Chem., 1961, 29, 277.
85 H. Sabzyan and F. Taghavi, Phys. Chem. Res., 2014, 2, 41. 86 R. F. W. Bader, Chem. Rev., 1991, 91, 893.

87 M. Daszkiewicz, CrystEngComm, 2013, 15, 10427.

88 X. Yu, H. Zhu and Y. Zeng, Int. J. Quantum Chem., 2016, 116, 1244.

89 O. E. Kasende, J. T. Muya, V. P. Nziko and S. Scheiner, J. Mol. Model., 2016, 22, 77.

90 O. E. Kasende, A. Matondo, J. T. Muya and S. Scheiner, Int. J. Quantum Chem., 2017, 117, 157.

91 T. Kikkawa, S. Ohba, Y. Saito, S. Kamata and S. Iwata, Acta Crystallogr., 1987, B43, 83.

92 M. Okuda, S. Ohba, Y. Saito, T. Ito and I. Shibuya, Acta Crystallogr., 1990, B46, 343. 